\title{
Some Pharmacological And Histological Studies On The Effect Of Neostigmine Injected Intrathecally
}

\author{
Fatma Zorob, Nemat El Baz*, Abd El Mawgood A. Ismaeil** \\ and Mona Radwan*
}

\author{
Anesthesia and*Pharmacology departments, Faculty of Medicine for Girls \\ ** Histology department, Faculty of Medicine for Men \\ Al Azhar University
}

\begin{abstract}
The spinal delivery of the cholinesterase inhibitor neostigmine yields analgesia and augments the analgesic effect of alpha-2 ( $\alpha-2)$ agonist.

To assess its activity, histological and pharmacological studies were designed to define its effect in two species; rats and cats.

Pharmacological assessment of intrathecally injected (it) neostigmine in cats showed a gradual increase in mean blood pressure (MBP) and heart rate (HR) at doses 2 $-16 \mu \mathrm{g} / \mathrm{kg}$ while a decrease in MBP and HR occurred at doses $32-64 \mu \mathrm{g} / \mathrm{kg}$. The intrathecal injection of atropine and phentolamine abolished the increase in MBP and HR produced by (it) neostigmine $(4 \mu \mathrm{g} / \mathrm{kg}$ ). In spinal cat preparation (it) neostigmine produced rapid rise in MBP at small $(4 \mu \mathrm{g} / \mathrm{kg})$ and large doses $(64 \mu \mathrm{g} / \mathrm{kg})$. In this study neostigmine counteracts the hypotensive effect and bradycardia produced by intrathecal injection of $\alpha-2$ agonist clonidine.

Histological study was performed on rats. They were divided into 5 groups representing control and 4 groups treated by neostigmine at 25, 50, 75 and $100 \mu \mathrm{g} / \mathrm{kg}$. After each injection, the animals were assessed for general behavior, and function. Arousal, motor coordination and motor tone measurement (A, MC and MT) revealed that Intrathecal injection of neostigmine resulted in dose-dependent decreased arousal, and motor coordination, and dose-dependent increase in motor tone.

The quantitative histological and cytochemical data demonstrated an initial increase in the nucleo-cytoplasmic ratio of the anterior horn cells up to $75 \mathrm{ug} / \mathrm{kg}$ followed by a decline in $100 \mathrm{ug} / \mathrm{kg}$ - treated animals. The cytoplasmic RNA content of the anterior horn cells showed an increase in the optical density that reached a maximum at $50 \mathrm{ug} / \mathrm{kg}$ followed by a decline at higher doses. The Golgi bodies increased in the cytoplasm of $25 \mathrm{ug} / \mathrm{kg}$ treated animals, the level became constant up til $75 \mathrm{ug} / \mathrm{kg}$, and started to decline at $100 \mathrm{ug} / \mathrm{kg}$. There was no change in the quantity of the myelinated nerve fibers, however, there was a dose dependent decline in their stainability with silver.

In conclusion:These results provide an evidence that the adverse events from neostigmine injected intrathecally appear to be affected by the dose injected which could be important in clinical practice
\end{abstract}




\section{Introduction}

Surgical trauma is a noxious stimulus of the body that produces a range of biologic alterations. The choice of anesthesia and postoperative pain reliever may have an important implication for postoperative patient outcome (14).

Intrathecal injection of neostig mine represents a cholinergic mechan ism of spinal analgesia. It inhibits the breakdown of the endogenous neurot ransmitter- acetycholine- which has been shown to cause analgesia(2) Also it potentiates analgesia from intrath ecally administered $\alpha-2$ adrenergic agonists in rats and sheep (7).

Clinical assessment in humans showed that intrathecal neostigmine causes dose dependent analgesia and side effects (nausea, vomiting, weakness, sedation), the degree of which depends on the amount of tonic release of acetylcholine (13).

Clinical trials of any new agent or new route of administration are gener ally performed using an open label, dose escalating design in healthy patients or volunteers (15). The focus of these studies is to assess the safety and estimate the relationship between dose and incidence of side effects. Laboratory studies demonstrated a dense binding of cholinergic ligands in the superficial dorsal horn; and microinjection of cholinergic agonists in this area inhibits excitation of dorsal horn neurons by electrical stimulations. However, the clinical utility of intrath ecally administered cholinergic agonist, neostigmine, may be limited by motor weakness caused by direct stimulation in the spinal cord ventral horn (21).

The aim of the present study is to evaluate the effect of intrathecal injection of neostigmine on the morphology and histochemistry of anterior horn cells in rats in which behavioral changes are also well observed. The phamacological effects of intrathecal neostigmine, either alone, or in combination with clonidine on the cardiovascular variables in cats are also tested in thus study.

\section{MATERIAL AND Methods Drugs}

Neostigmine methylsulphate : Eipistgmin vial ( $2.5 \mathrm{mg} / \mathrm{ml}$, Epico)

Clonidine hydrochloride

Catapresan ampoule (150 mg/ml), Boehringer Ingelheim .

Atropine sulphate : ampoule (1 $\mathrm{mg} / \mathrm{ml}$ )Cid (Misr)

Epinephrine : ampoule $(1 \mathrm{mg} / \mathrm{ml})$.

Phentolaminc :Regitine ampoule ( $10 \mathrm{mg} / \mathrm{ml}$ )(Novartis)

Doses: therapeutic doses were converted to the animal dose according to surface area (19).

\section{Injection protocol}

Dilution of each drug was made with an aseptic technique using sterile saline $(0.9 \% \mathrm{NaCl})$. In rats, the drug was delivered in a volume of $10 \mu \mathrm{l}$, while in cats it was delivered in a volume of $1 \mathrm{ml}$.

After each injection, a second 10 $\mu \mathrm{l}$ or $1 \mathrm{ml}$ of sterile saline was injected to flush the needle in each animal respectively.

The study was divided into two parts.

\section{Part I: Pharmacological studies} In Vivo studies

\section{1-Experiments on arterial blood pressure and electrocardiograph of anesthetized cats (11).}

Cats of both sexes, weighing $2-3 \mathrm{~kg}$, were anesthetized by intraperitoneal injection of pentobarbitone $(20 \mathrm{mg} / \mathrm{kg})$.

The femoral artery was exposed, cannulated and the cannula was conne cted to a mercury manometer provided with a lever writing on moving smoked 


\section{Some Pharmacological And Histological Studies}

kymograph drum. Electrocardiograph (ECG) was recorded throughout the experiment using the standard lead (lead 11) speed record $25 \mathrm{~mm} / \mathrm{sec}$ (Siemens model cardiostat ). The mean blood pressure (MBP) (diastolic blood pressure $+1 / 3$ pulse pressure) and ECG were simultaneously recorded.

\section{The following experiments were done:}

- The effect of IT neostigmine (2 $64 \mu \mathrm{g} / \mathrm{kg}$ ) on MBP and ECG of anesthetized cats was recorded.

- The effect of IT neostigmine on MBP of anesthetized cats was examined before and after IT injection of the muscarinic antagonist, atropine $(500 \mu \mathrm{g} / \mathrm{kg})$; and the noradrenergic antagonist, phentolamine $(8 \mu \mathrm{g} / \mathrm{kg})$.

- The interaction between IT neostigmine and clonidine (25 $\mu \mathrm{g} / \mathrm{kg}$ ) on MBP of anesthetized cats was shown by giving each drug alone and when IT clonidine was injected 60 minutes after IT neostigmine.

\section{2- Spinal cat Preparations:}

The effect of IT neostigmine in small dose $(4 \mu \mathrm{g} / \mathrm{kg})$ and in large dose $(64 \mu \mathrm{g} / \mathrm{kg})$ was examined on MBP of spinal cat preparation. The anesthetized animal was placed on its back and both carotid arteries were tied as high as possible in the neck. The animal was then placed on its abdomen and the head was flexed forward. Care being taken to see that the tracheal cannula and trachea were not kinked. A longitudinal cut was made in the middle line of the skull down to the back of the neck. The skin and the muscle layers were retracted, the occipital bone at the back of the skull and the first cervical vertebra were exposed. The cisterna magna was felt between the two bones as a fluid -filled mass; when this was cleaned, it became transparent and the underlying spinal cord was seen. The animal was connected to the respiratory pump. The cisterna magna was opened and the spinal cord was cut with a thick blunt edged probe about $5 \mathrm{~mm}$ width, by $1-2 \mathrm{~mm}$ thickness.A special rod, maximum diameter $5 \mathrm{~mm}$ was pushed into the brain through the opening at the base of the skull, the foramen magnum, and stirred around in order to destroy the brain.

\section{Part II : Histological study}

\section{Repeated fixed- dosing.}

The test was conducted on 30 rats (200 g each), they were anesthe tized with ether. The surgical field on the dorsum of the lumbosacral region was prepared with betadine and alcohol.

A skin incision was made and muscles were retracted to expose the vertebral column. A fine needle was inserted into the lumber inter-vertebral space, fixed and secured. On anesthetic recovery, if the rat showed a deficit on hindlimb function it was excluded from the study.

The rats were divided into five groups ( $n=6$ each group). Intrathecal (it) neostigmine was injected in doses of 25 , 50,75 and $100 \mu \mathrm{g} / \mathrm{kg}$ body weight which were equivalent to $250 \mu \mathrm{g}, 500 \mu \mathrm{g}, 750$ $\mu \mathrm{g}$ and $1 \mathrm{mg}$ intrathecal neostigmine human dose. The rats were assigned to one of the following treatments:

( It) saline (control group ) $(n=6)$, (it) neostigmine $(25 \mu \mathrm{g} / \mathrm{kg})$, (it) neosti gmine $(50 \mu \mathrm{g} / \mathrm{kg})$, (it) neostigmine $(75$ $\mu \mathrm{g} / \mathrm{kg} \mathrm{)} \mathrm{and} \mathrm{(it)} \mathrm{neostigmine}$ $(100 \mu \mathrm{g} / \mathrm{kg})$. Each group received bolus injections for four repeated doses, 30 minutes apart. After each injection the animals were assessed for general behavior and function as described in table (1). Tremors and salivation were also assessed. The time of each inject ion was arranged to coincide with the 
time of peak concentration of neostig mine in the cerebrospinal fluid after the previous injection of this drug. This time ranged from 5-30 min ( 21,22).

\section{Rat Sacrifice}

On the second day, the animals were sacrificed and the vertebral column from the lower sacral to the cervical area was dissected out. Excess tissue was removed leaving the vertebral column intact. It was fixed in neutral buffered formol saline (NBFS) for at least one week. The spinal cord at the level of cervical region was dissected out; cut and $0.5 \mathrm{~mm}$ long specimen were fixed in NBFS for 48 hours. The tissues were processed for paraffin embedding and blocking. Thin $(6 \mu \mathrm{m})$ sections were mounted on clean microscopic glass slides and stained with the following staining techniques: Hematoxylene and Eosin stain (H,E stain ) (8).

toluidine blue for Nissle granules (8).

Methyl green pyronin for RNA and DNA (6) .

Nauta and Gygax silver for nerve fibres (18) .

\section{Quantitative analysis :-}

The following parameters were measured using computerized micros copic image analyser with Optimas software version 6.21 (Media Cybernetics Inc.). Two slides from each animal were used to obtain data representing each of the following parameters :-

\section{1-Nucleo -Cytoplasmic ratio (NCR):}

The volume of nerve cell nuclei $(\mathrm{NV})$, and the volume of the cells (CV) was measured. The NCR was calculated from the following equation:

$$
\mathrm{NCR}=(\mathrm{NV} \times 100 / \mathrm{CV})
$$

\section{2- RNA content:}

The cell content of RNA was measured in nerve cells stained with pyronin. The content was expressed as optical density values according to the Lambert law (26).

\section{3- Golgi body content:}

The Golgi bodies were evaluated as the intracellular, non-nuclear, silver stained material.

\section{4- Nerve fiber evaluation:}

The volume of nerve fibers was evaluated as the area occupied by the fibers stained by silver in a fixed area box and sections of the same thickness. The change in myelin properties was measured as the optical density (concentration) of stained myelin.

Data were collected and analysed using student's test. Results were expressed as mean \pm standard deviation $\mathrm{P}<0.05$ and $\mathrm{P}<0.001$ were considered statistically significant.

\section{Results}

\section{Part I: Pharmacological Studies}

Intrathecal injection (it) of neos tigmine in small doses $(2-16 \mu \mathrm{g} / \mathrm{kg})$ produced a dose dependent increase of mean arterial blood pressure (MBP) and heart rate (HR) of anesthetized cats. This effect appeared $15 \mathrm{~min}$ after injection and increased gradually until it reached the maximum effect at 60 miutes. The increase in MBP was statistically significant while changes in heart rate were insignificant (Figure 1,2 , table 2 ).

The muscarinic antagonist, atropine, injected intra-thecally at dose $500 \mu \mathrm{g} / \mathrm{kg}$ abolished the increase in MBP produced by (it) neostigmine at $4 \mu \mathrm{g} / \mathrm{kg}$ (Figure 3 ). Also, the adrenergic antagonist, phentolamine, injected intrat -hecally at a dose of $8 \mu \mathrm{g} / \mathrm{kg}$ abolished the increase of MBP produced by it neostigmine at $4 \mu \mathrm{g} / \mathrm{kg}$ ( Figure 4 ).

However, (it) neostigmine in large doses (32-64 $\mu \mathrm{g} / \mathrm{kg})$, produced a decrease of MBP of anesthetized cats (figure 5), which was abolished by (it) atropine (Fig.6 ).

After destruction of the brain in spinal cat preparation, it neostigmine in small doses $(4 \mu \mathrm{g} / \mathrm{kg})$ and in large doses 


\section{Some Pharmacological And Histological Studies}

$(64 \mu \mathrm{g} / \mathrm{kg})$ produced a rapid rise of MBP ( Figures 7,8).

Although (it) neostigmine, at $4 \mu \mathrm{g} / \mathrm{kg}$, produced an increase in MBP and HR of anesthetized cats; (it) clonidine $(25 \mu \mathrm{g} / \mathrm{kg})$ decreased both HR and MBP in these animals. When neostigmine was injected intrathecaly, at a dose of $4 \mu \mathrm{g} / \mathrm{kg}, 60$ minutes before clonidine, it counteracted the hypotension and bradycardia produced by clonidine (Figure 9,10).

\section{Part II: Histological studies} Arousal Motor coordination and Motor tone measurement (AMC and MI ):

The intrathecal injection of neostigmine resulted in decreased arousal which was dose dependent (figure 11). This was evidenced by decreased activity with increasing dose to no organized response to pinch of the forepaw.

Decreased motor coordination was also observed by increasing the dose of neostgmine (figure 12). The rats ambulated asymmetrically. This became extreme at the 2nd dose of $75 \mu \mathrm{g} / \mathrm{kg}$ neostigmine, while the rats could not functionally move in a forward fashion with the 3rd and 4th injections of the same dose. This effect was observed with $100 \mu \mathrm{g} / \mathrm{kg}$ neostigmine from the start of drug injection and throughout the study period.

Increasing the dose of intrath ecally injected neostigmine resulted in an increase in motor tone (figure 13). This was evidenced by increasing stiffness of the chest wall with extension of limbs. Tremors were observed when the paw was gently withdrawn. Convulsions were seen $5 \mathrm{~min}$ after each intrathecal injection of $100 \mu \mathrm{g} / \mathrm{kg}$ neostigmine.

Comparing the four doses injected intrathecally, tremors were observed with injection of $100>75>50$ $>25 \mu \mathrm{g} / \mathrm{kg}$. The onset of increased tone was observed $5 \mathrm{~min}$ after injection. Like motor tone, salivation was observed
5 min after injection of each of the 75 and $100 \mu \mathrm{g} / \mathrm{kg}$. Salivation was profuse with $100 \mu \mathrm{g} / \mathrm{kg}$ neostigmine throughout the study period. Also, intrathecal injection of $100 \mu \mathrm{g} / \mathrm{kg}$ neostigmine resulted in diarrhea and protrusion of the eye throughout this study.

\section{Structural and cytochemical study}

The general structure of the ventral column cells and fibers of control and treated animal spinal cord shows no clear cut changes (plate 1). However, the nucleo cytoplasmic ratio of the nerve cells, which is one of the parameters used to indicate nuclear activity, is different in treated animals compared to control ( figure 14). The ratio increases as the dose increases up to $75 \mu \mathrm{g} . / \mathrm{kg}$ of intrathecal neostigmine injection, then decreased to a level higher than control in animals injected with $100 \mu \mathrm{g} / \mathrm{kg}$.

The cytoplasmic content of Nissl granules (plate 2) and cytoplasmic RNA in pyronin stained sections of the ventral horn cells (plate 3), shows definite changes in treated compared to control animals. While the optical density value (table 3, figure 15) relative to the cytoplasmic RNA content of anterior horn nerve cells of control animals was $0.374 \pm 0.086$, it was 0.398 \pm 0.047 for that of $25 \mu \mathrm{g} / \mathrm{kg}$, and 0.401 \pm 0.060 for $50 \mu \mathrm{g} / \mathrm{kg}, 0.381 \pm .046$ for $75 \mu \mathrm{g} / \mathrm{kg}$, and $0.367 \pm 0.043$ for 100 $\mu \mathrm{g} / \mathrm{kg}$.

In silver stained sections, the Golgi bodies appear as grayish granules in the cytoplasm of nerve cells, while the nerve fibers are stained darkly (plate 4). Measurement of the density of the golgi bodies (table 4) shows that the Golgi body content of anterior horn nerve cells of control animals was $0.2187 \pm 0.036$, it was $0.362 \pm 0.122$ for that of $25 \mu \mathrm{g} / \mathrm{kg}$, and $0.351 \pm$ 0.132 for $50 \mu \mathrm{g} / \mathrm{kg}, 0.354 \pm .105$ for $75 \mu \mathrm{g} / \mathrm{kg}$, and $0.269 \pm 0.068$ for 100 $\mu \mathrm{g} / \mathrm{kg}$.. The general trend of the 
obtained curve is similar to that of cytoplasmic RNA content (figure 16).

Changes in the myelinated fibers in the ventral horn of the spinal cord of control and treated animals have been evaluated by measurement of two factors: the change in the area occupied by these fibers relative to fixed area of the section (degenerative changes), and the density of stained myelin in these fibers (table5, figure 17). There was no change in the area occupied by the fibers. The density of silver stained myelin was inversely proportional to the dose of the drug.

Table(1): Summary Description of Arousal / Motor Coordination/MotorTone Measures ( Yaksh et al 1995)

\begin{tabular}{|c|c|}
\hline $\begin{array}{l}\text { Arousal } \\
\quad+3\end{array}$ & $\begin{array}{l}\text { Continued rapid movement ; continuous squeaking ;extreme attempts to bite or } \\
\text { escape when handled;light tactile stimulation drives vigorous squeaking ; escape / } \\
\text { aggressive behavior ; spontaneous jumping }\end{array}$ \\
\hline+2 & $\begin{array}{l}\text { Continuous activity ;frequent squeaking behavior ; exaggerated response to light touch } \\
\text { (squeaking, escape, gnawing at probe }\end{array}$ \\
\hline+1 & $\begin{array}{l}\text { Increased locomotor activity in cage ;continual grooming ; unable to position on } \\
\text { catalepsy test }\end{array}$ \\
\hline 0 & $\begin{array}{l}\text { Normal spontaneous activity ; occasional grooming ; intermittent activity in } \\
\text { novel environment ; rapid( }<1 \text { to } 2 \text { s)recovery from catalepsy test ; orients to light } \\
\text { touch ; no agitation displayed when picked up and strocked }\end{array}$ \\
\hline-1 & $\begin{array}{l}\text { Decreased spontaneous activity / delayed catalepsy dismount }(\text { rat })(>5 s,<20 \text { s) } \\
\text { responds to repetitive light strocking or hand clap }\end{array}$ \\
\hline-2 & $\begin{array}{l}\text { No spontaneous behavior ; no dismount from catalepsy bar (rat) ( }>20 \text { s); delayed } \\
\text { response to continuous pinch of fore or hind paws }\end{array}$ \\
\hline-3 & Comatose ; no organized response to pinch of the fore/hind paw or hand clap \\
\hline $\begin{array}{l}\text { Motor Coordi } \\
0\end{array}$ & $\begin{array}{l}\text { ation } \\
\text { Normal symmetric posture, ambulates with normal symmetry ; able to spontaneously } \\
\text { stand in grooming posture ; normal placing and stepping response; normal coordinated } \\
\text { hindquarter righting response }\end{array}$ \\
\hline-1 & Ambulates asymmetrically ; weak placing and stepping response ; weak righting response \\
\hline-2 & $\begin{array}{l}\text { Ambulates with extreme asymmetry; no placing and stepping response; one or more limbs } \\
\text { cannot participate in righting response }\end{array}$ \\
\hline-3 & Unable to functionally move in a forward fashion \\
\hline $\begin{array}{l}\text { Motor tone } \\
\quad+3 \\
+2\end{array}$ & $\begin{array}{l}\text { Extreme rigidity ; "barrel chest" feeling ;legs in extreme extension } \\
\text { Moderate rigidity; resistance to movement of the hind limbs ; increased tone observed when } \\
\text { mild pressure is applied to the chest wall }\end{array}$ \\
\hline+1 & Mild rigidity ; stiffness associated with extension or flexion of limbs \\
\hline 0 & Normal tone ; ready passive extension and flexion of hind Limb; normal chest wall elasticity \\
\hline-1 & $\begin{array}{l}\text { Mild decrease in tone ; limbs can be held in passive extension without resistance ; animal } \\
\text { can retain a normal crouching posture }\end{array}$ \\
\hline-2 & $\begin{array}{l}\text { Moderate decrease in tone ; animal in passive extension with no limb withdrawal observed } \\
\text { after slight hyperextension ;animal unable to maintain normal crouching posture even } \\
\text { when maximally aroused }\end{array}$ \\
\hline-3 & $\begin{array}{l}\text { Animal has no posture tone;thoracic lordosis curvature absent; no withdrawal observed even } \\
\text { with extreme limb extension }\end{array}$ \\
\hline
\end{tabular}




\section{Some Pharmacological And Histological Studies}

Table(2) : Effect of intrathecal neostigmine $(2-64 \mu \mathrm{g} / \mathrm{Kg})$ on the mean Arterial blood pressure of anesthetized cats (mean \pm SD)

\begin{tabular}{|ccccccc|}
\hline $\begin{array}{r}\text { Time } \\
(\mathrm{min})\end{array}$ & $2 \mu \mathrm{g} / \mathrm{kg}$ & $4 \mu \mathrm{g} / \mathrm{kg}$ & $8 \mu \mathrm{g} / \mathrm{kg}$ & $16 \mu \mathrm{g} / \mathrm{kg}$ & $32 \mu \mathrm{g} / \mathrm{kg}$ & $64 \mu \mathrm{g} / \mathrm{kg}$ \\
0 & $101 \pm 2$ & $98 \pm 6$ & $100 \pm 4$ & $99 \pm 4$ & $100 \pm 3$ & $97 \pm 6$ \\
15 & $103 \pm 4$ & 1023 & $105 \pm 2^{*}$ & $107 \pm 2^{*}$ & $99 \pm 3$ & $95 \pm 2$ \\
30 & $105 \pm 4^{*}$ & $107 \pm 5^{\star}$ & $112 \pm 7^{* *}$ & $115 \pm 8^{* *}$ & $96 \pm 1$ & $90 \pm 6^{*}$ \\
45 & $109 \pm 2^{\star *}$ & $112 \pm 6^{* *}$ & $120 \pm 4^{* *}$ & $124 \pm 2^{* *}$ & $92 \pm 4^{* *}$ & $81 \pm 7^{* *}$ \\
60 & $111 \pm 5^{\star *}$ & $120 \pm 4^{* *}$ & $125 \pm 5^{* *}$ & $133 \pm 6^{* *}$ & $91 \pm 1^{* *}$ & $85 \pm 3^{* *}$ \\
\hline
\end{tabular}

${ }^{*} \mathrm{P}<0.05 \quad{ }^{* *} \mathrm{P}<0.001$

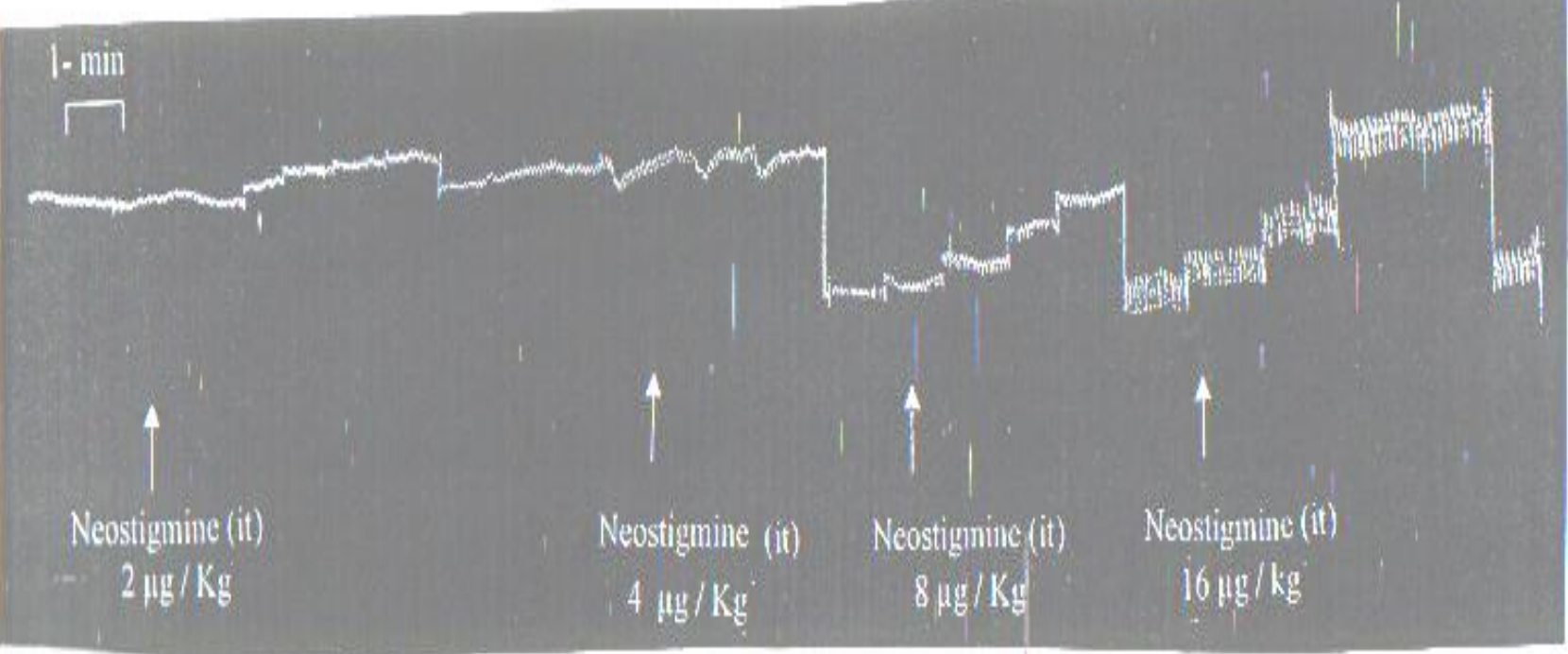

figure (1) : The effect of neostigmine injected intrathecally (it ) $(2-16 \mu \mathrm{g} / \mathrm{kg})$ on the mean arterial blood pressure of the anesthetized cat 


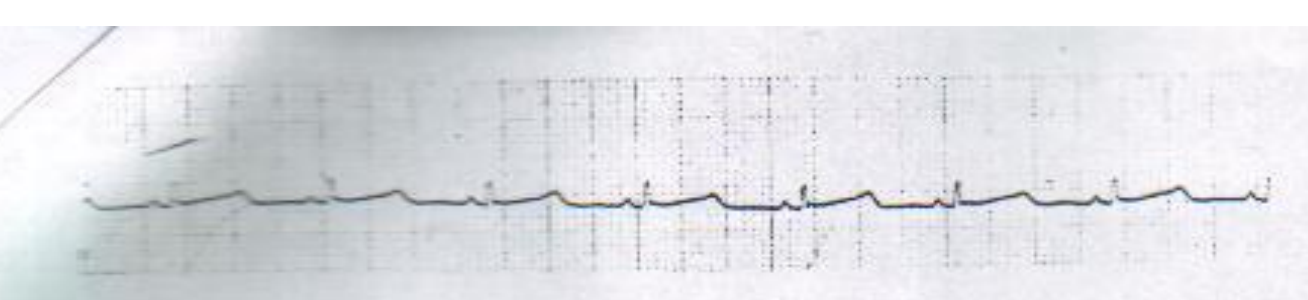

Baseline

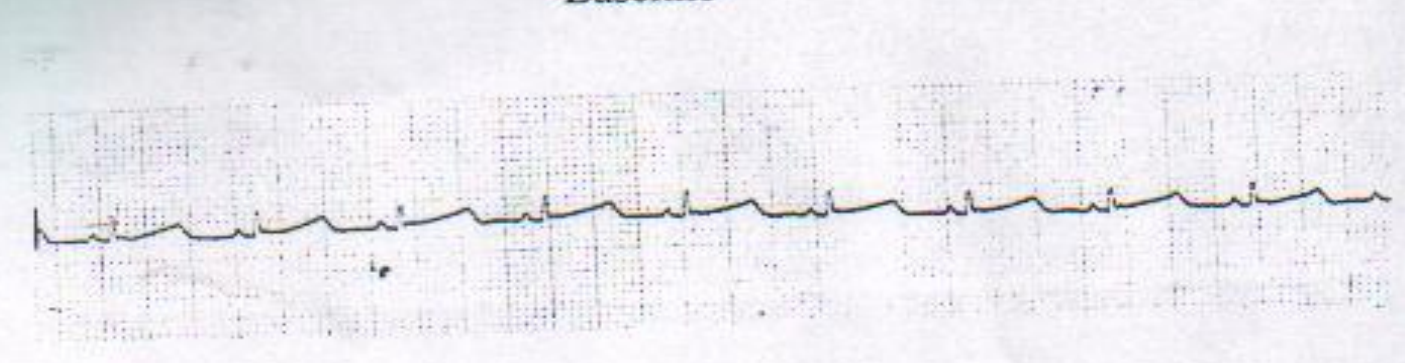

Neostigmine (it) $2 \mu \mathrm{g} / \mathrm{kg}$

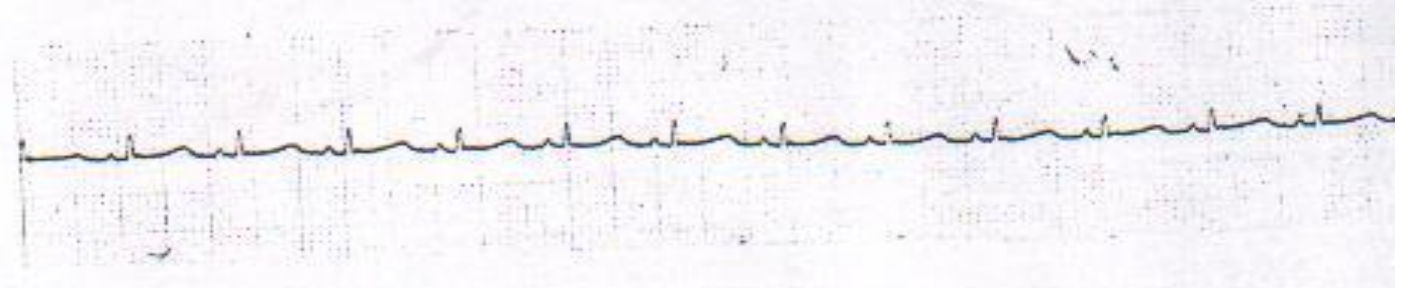

Neostigmine (it) $4 \mu \mathrm{g} / \mathrm{kg}$

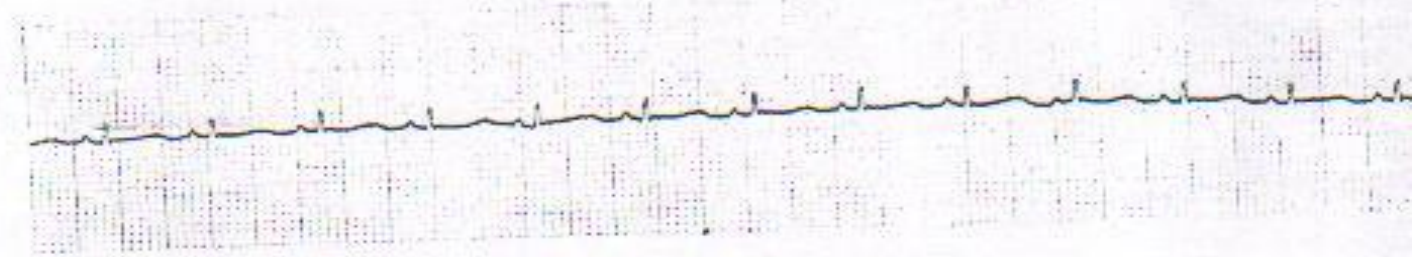

Neostigmine (it) $8 \mu \mathrm{g} / \mathrm{kg}$

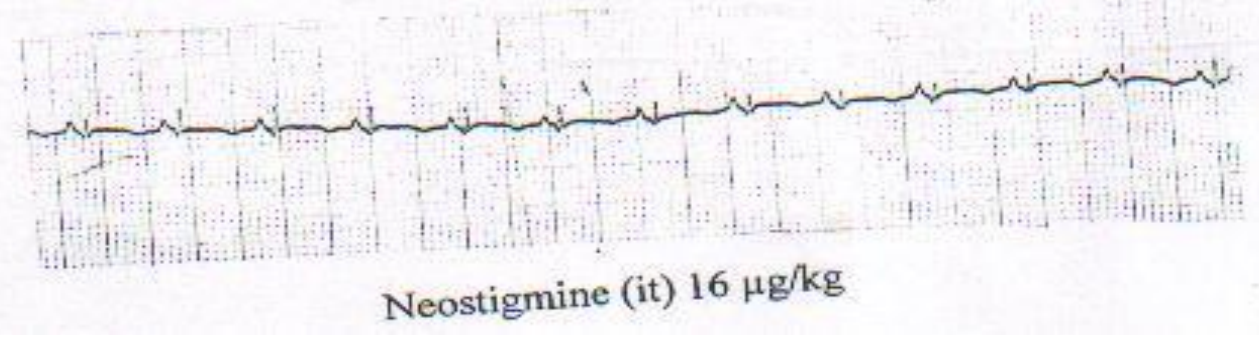

figure (2) : The effect of neostigmine injected intrathecally (it ) $(2-16 \mu \mathrm{g} / \mathrm{kg})$ on the heart rate of the anesthetized cat. 


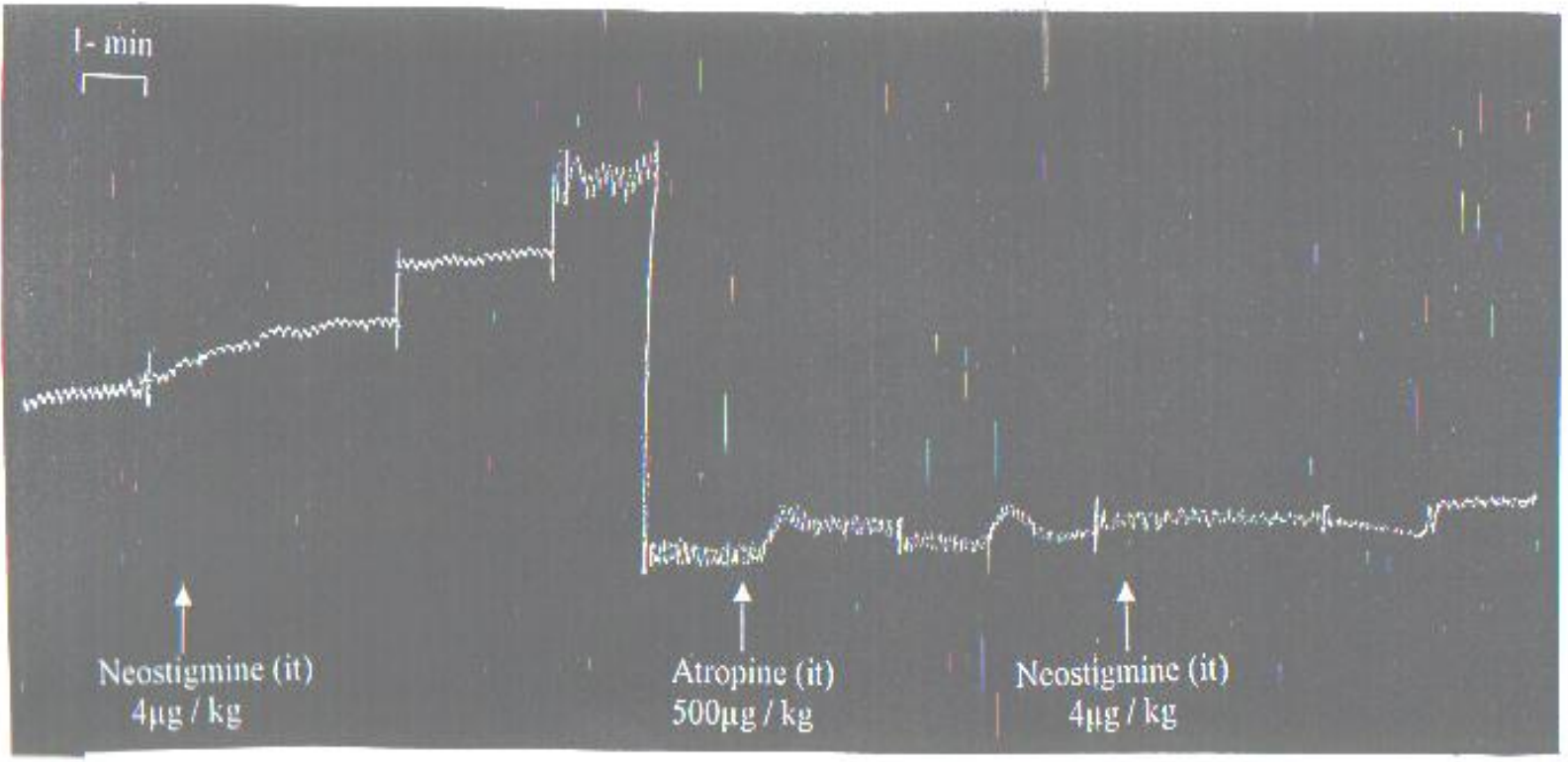

figure (3) : The effect of neostigmine injected intrathecally (it ) $4 \mu \mathrm{g} / \mathrm{kg}$ on the mean arterial blood pressure of the anesthetized cat after blocking the muscarinic receptors by atropine injected intrathecally ( $500 \mu \mathrm{g} / \mathrm{kg}$ )

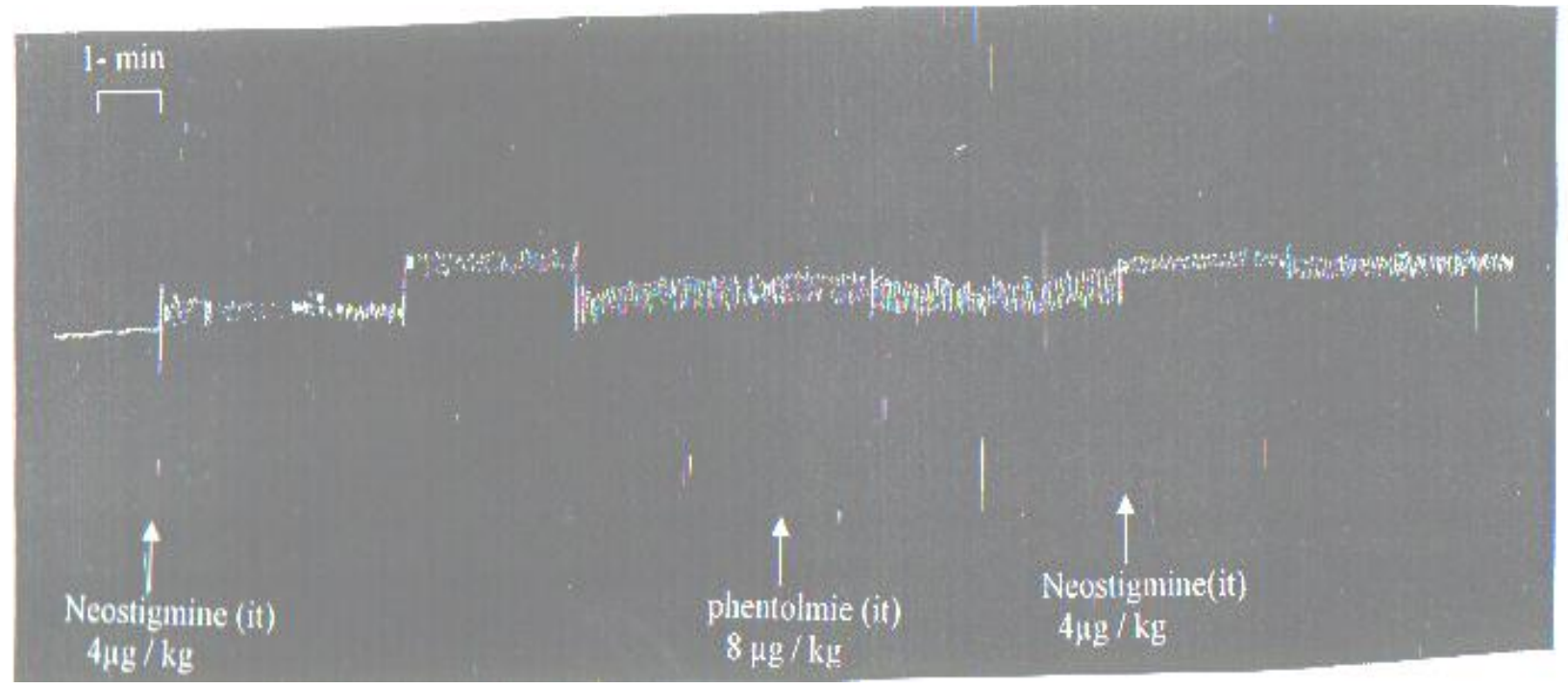

figure (4) : The effect of neostigmine injected intrathecally (it ) $4 \mu \mathrm{g} / \mathrm{kg}$ on the mean arterial blood pressure of the anesthetized cat after blocking the adrenergic receptors by phentolamine injected intrathecally ( $8 \mu \mathrm{g} / \mathrm{kg}$ ) 


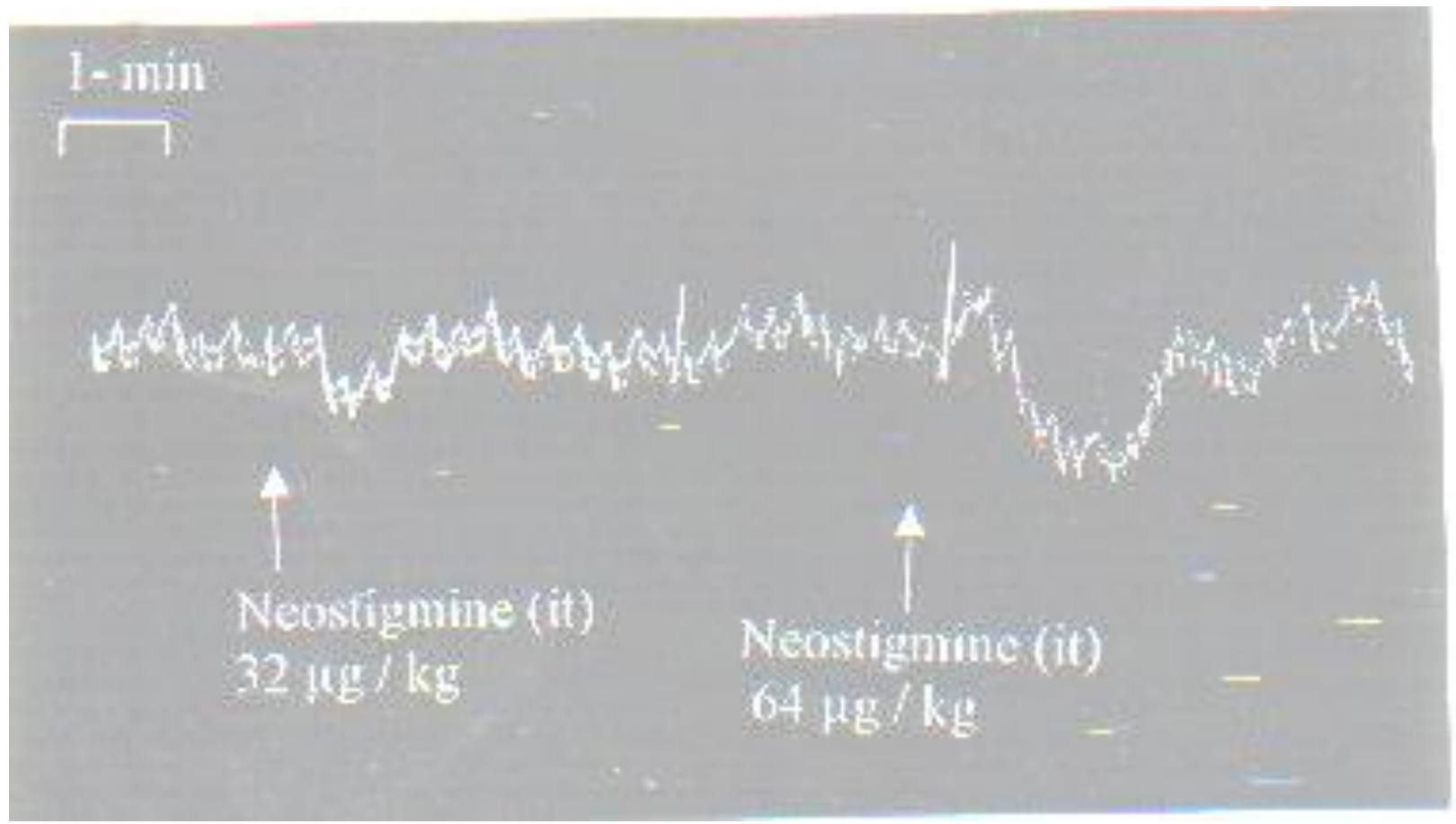

figure (5) : The effect of large doses of neostigmine injected intrathecally (it ) $32 \mu \mathrm{g} / \mathrm{kg}$ and $64 \mu \mathrm{g} / \mathrm{kg}$ on the mean arterial blood pressure of the anesthetized cat.

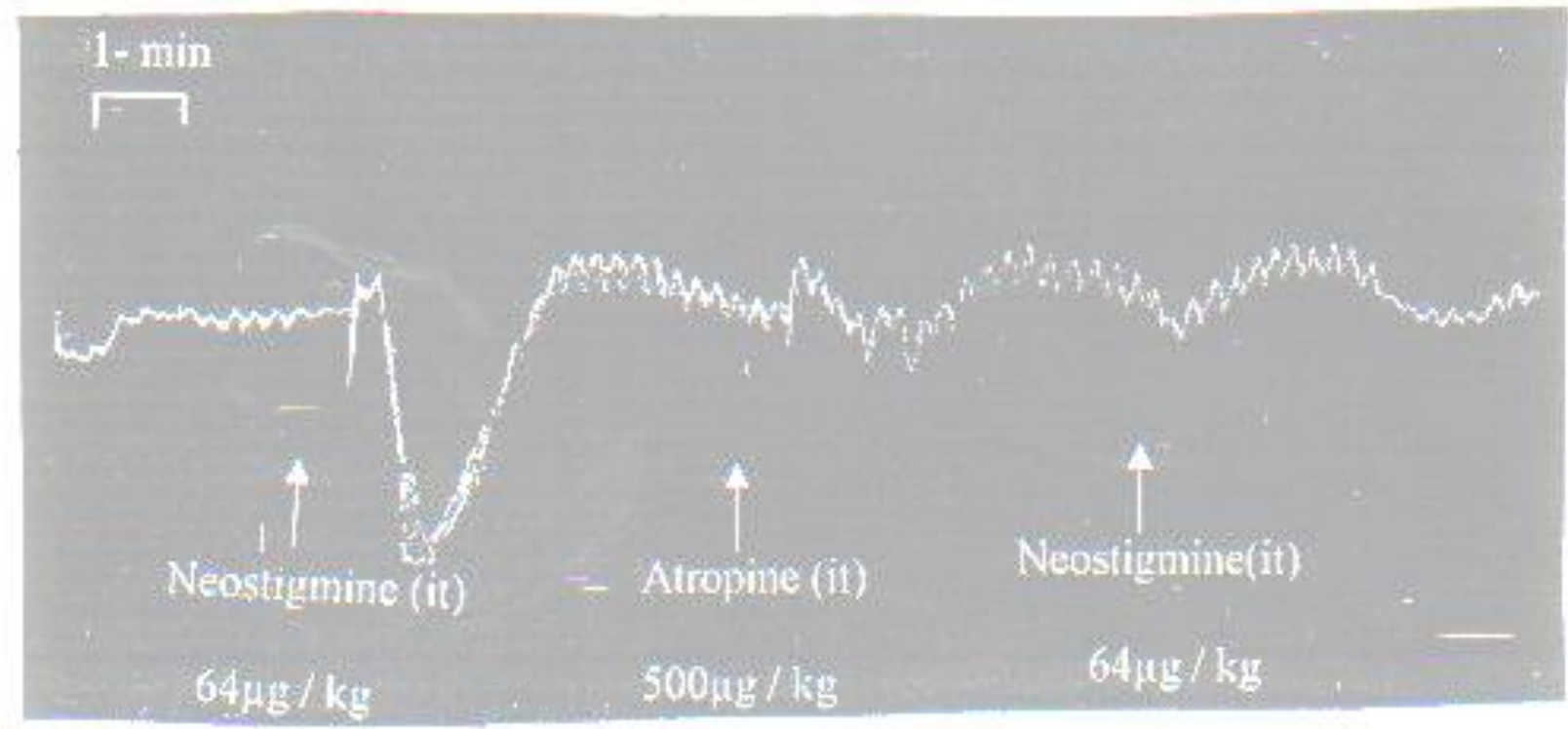

figure (6) : The effect of neostigmine injected intrathecally (it ) before and after intrathecal injection of nuscarinic receptor antagonist atropine $(500 \mu \mathrm{g} / \mathrm{kg})$ 


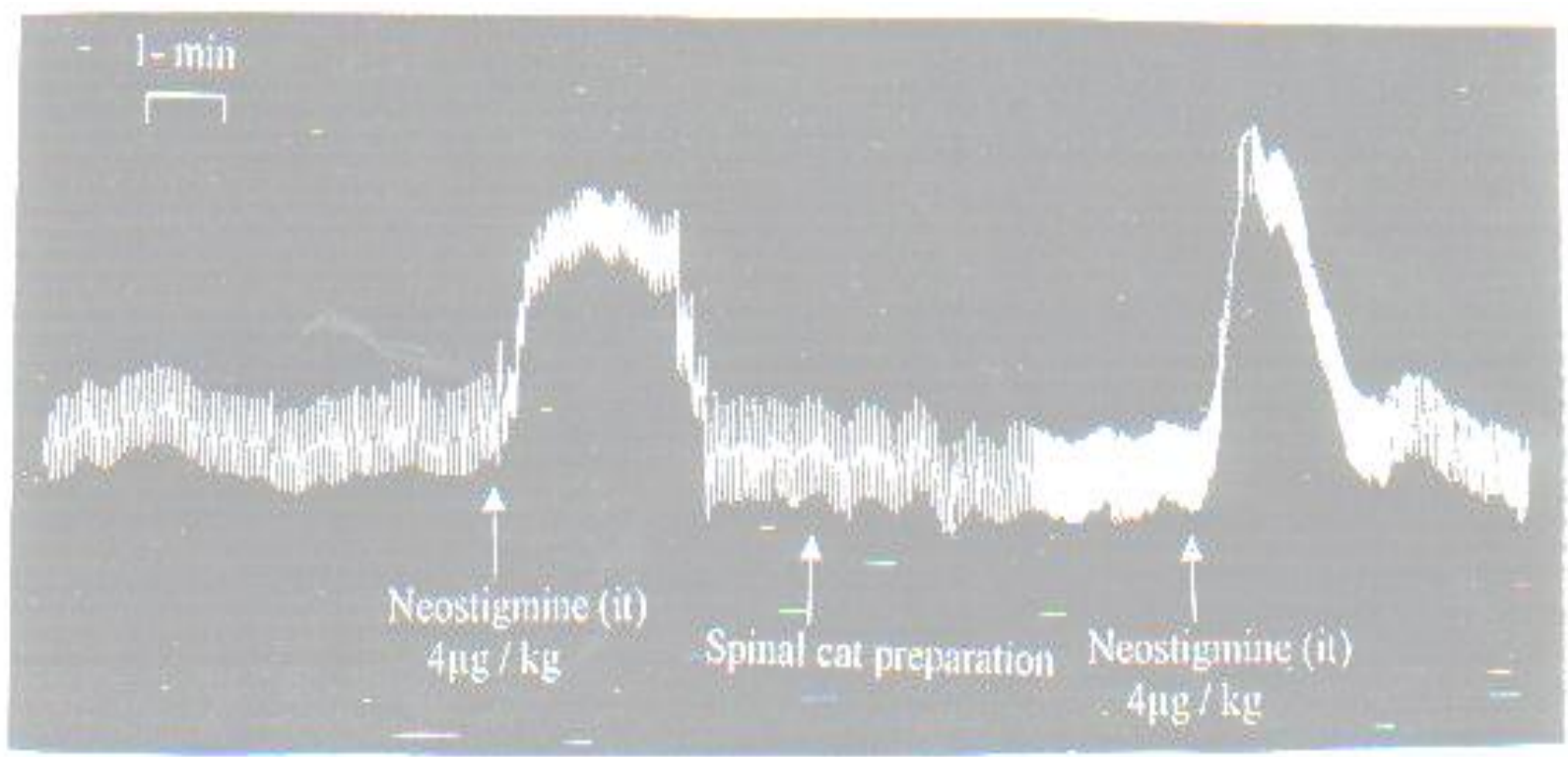

figure (7) : Spinal cat preparation, the effect of neostigmine injected intrathecally (it ) $(4 \mu \mathrm{g} / \mathrm{kg})$ before and after destruction of the brain .

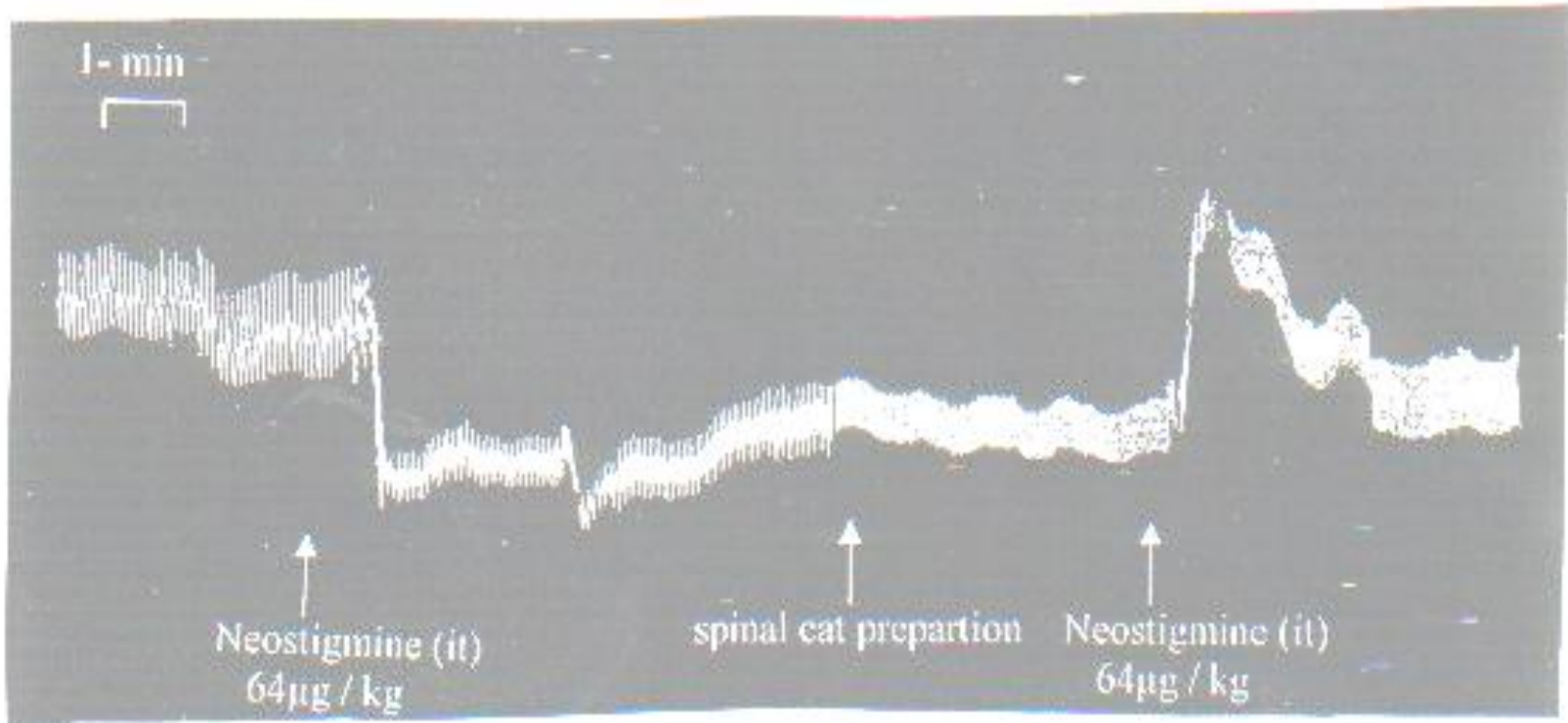

figure (8) : Spinal cat preparation, the effect of neostigmine injected intrathecally (it ) $(64 \mu \mathrm{g} / \mathrm{kg})$ before and after destruction of the brain . 


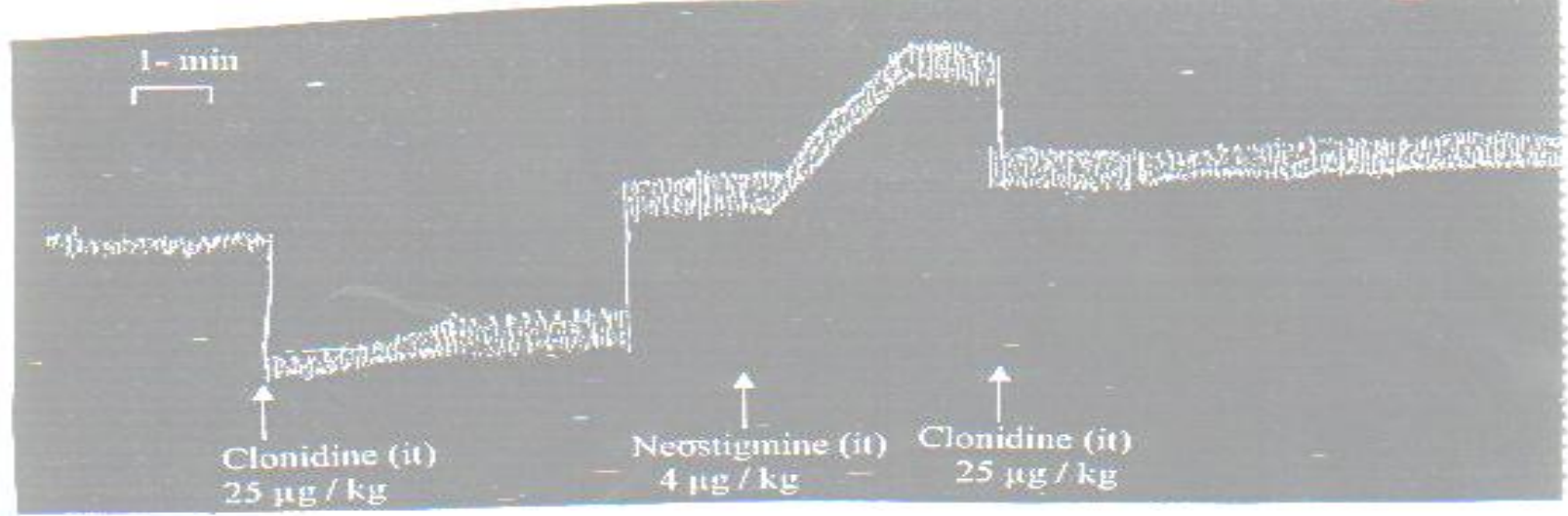

figure (9) : The interaction between clonidinde injected intrathecally ( it ) $(25 \mu \mathrm{g} / \mathrm{kg}$ ) and neostigmine injected intrathecally $(4 \mu \mathrm{g} / \mathrm{kg})$ on the mean arterial blood pressure of the anesthetized cat.

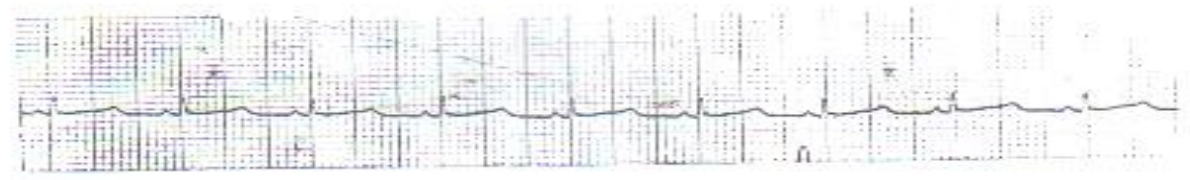

Baseline

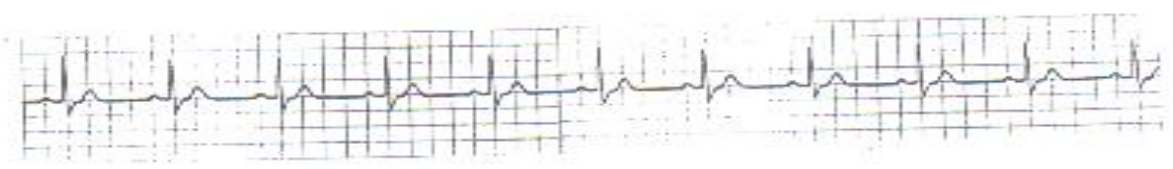

Clonidine (it) $25 \mu \mathrm{g} / \mathrm{kg}$

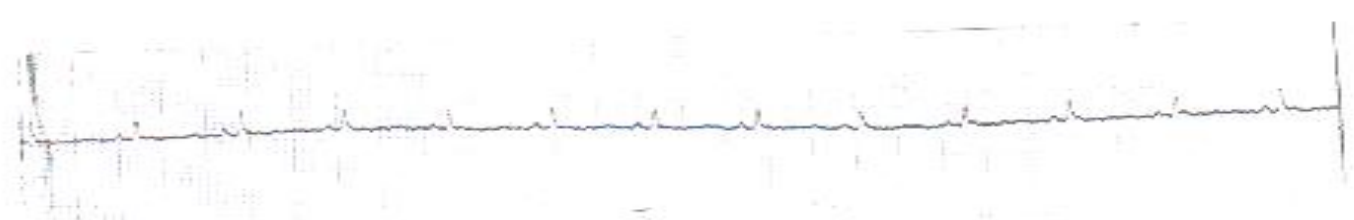

Neostigmine (it) $4 \mu \mathrm{g} / \mathrm{kg}$

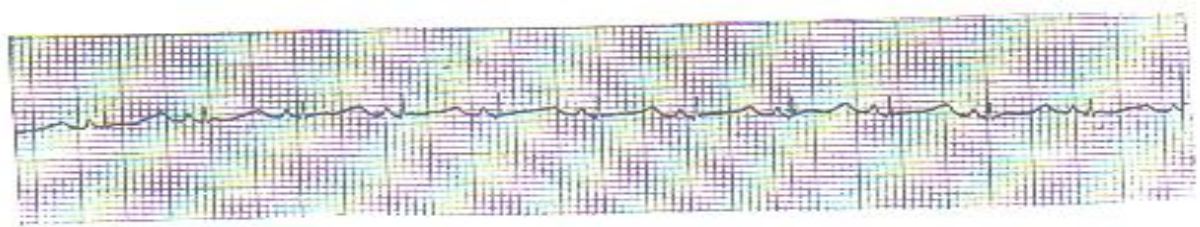

Clonidine (it) $25 \mu \mathrm{g} / \mathrm{kg}$

figure (10) : The interaction between clonidind injected intrathecally ( it ) $(25 \mu \mathrm{g} / \mathrm{kg}$ ) and neostigmine injected intrathecally (it) $(4 \mu \mathrm{g} / \mathrm{kg})$ on theheart rate of anesthetized cat. 
Some Pharmacological And Histological Studies

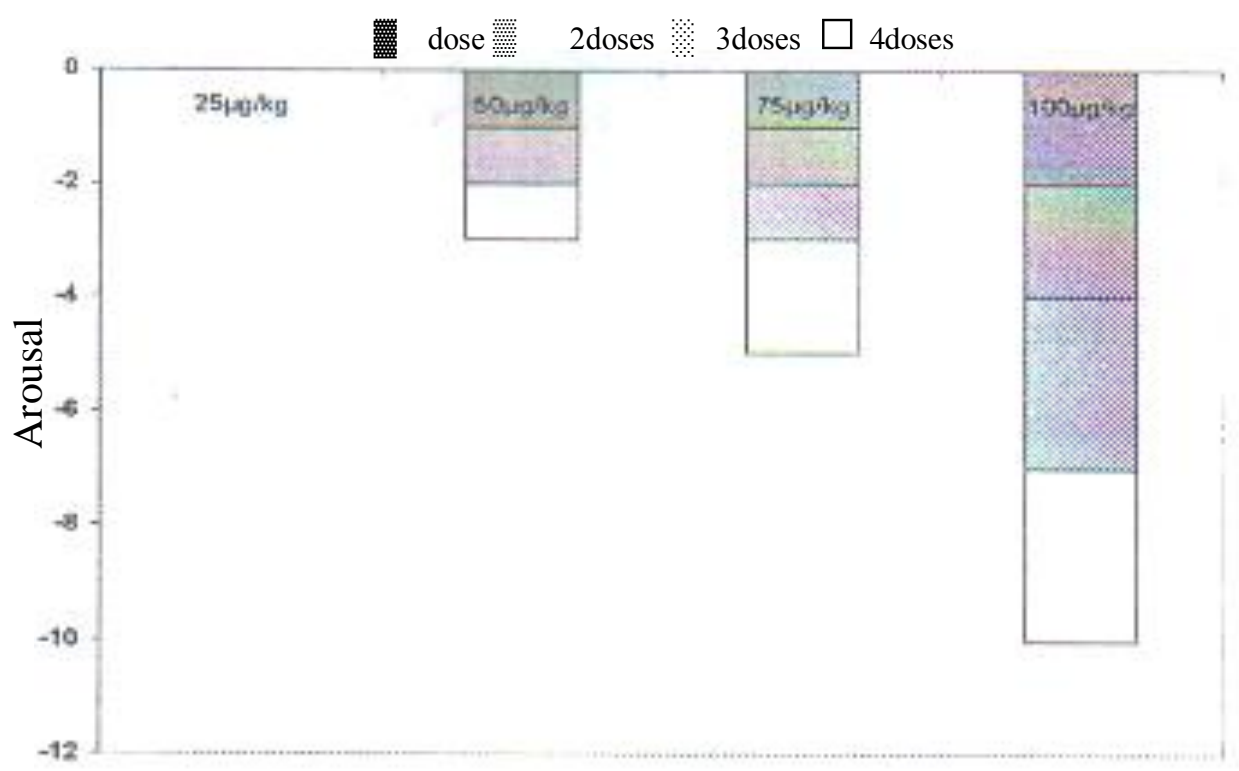

figure (11): Effect of different doses of intrathecally injected neostigmine on the activity to no organized response to pinch of the forepaw.

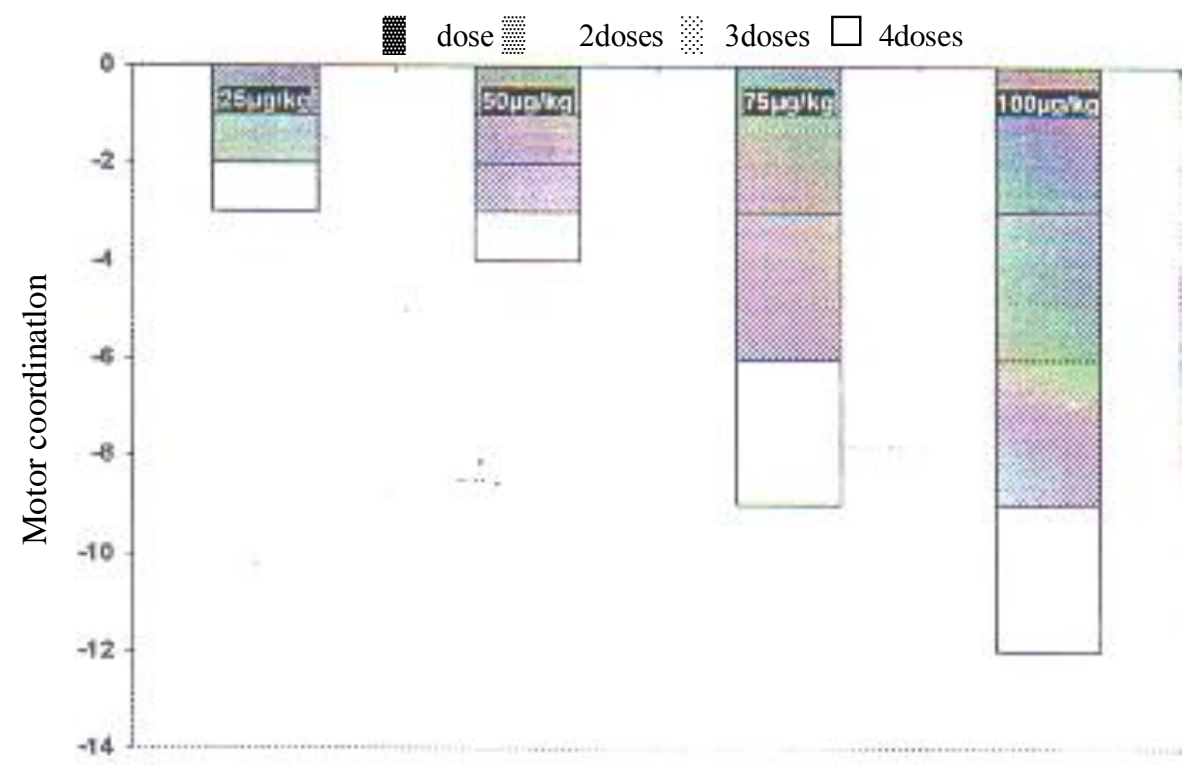

figure (12) : Effect of different doses of intrathecally injected neostigmine on motor coordination . 
Fatma Zorob, et al

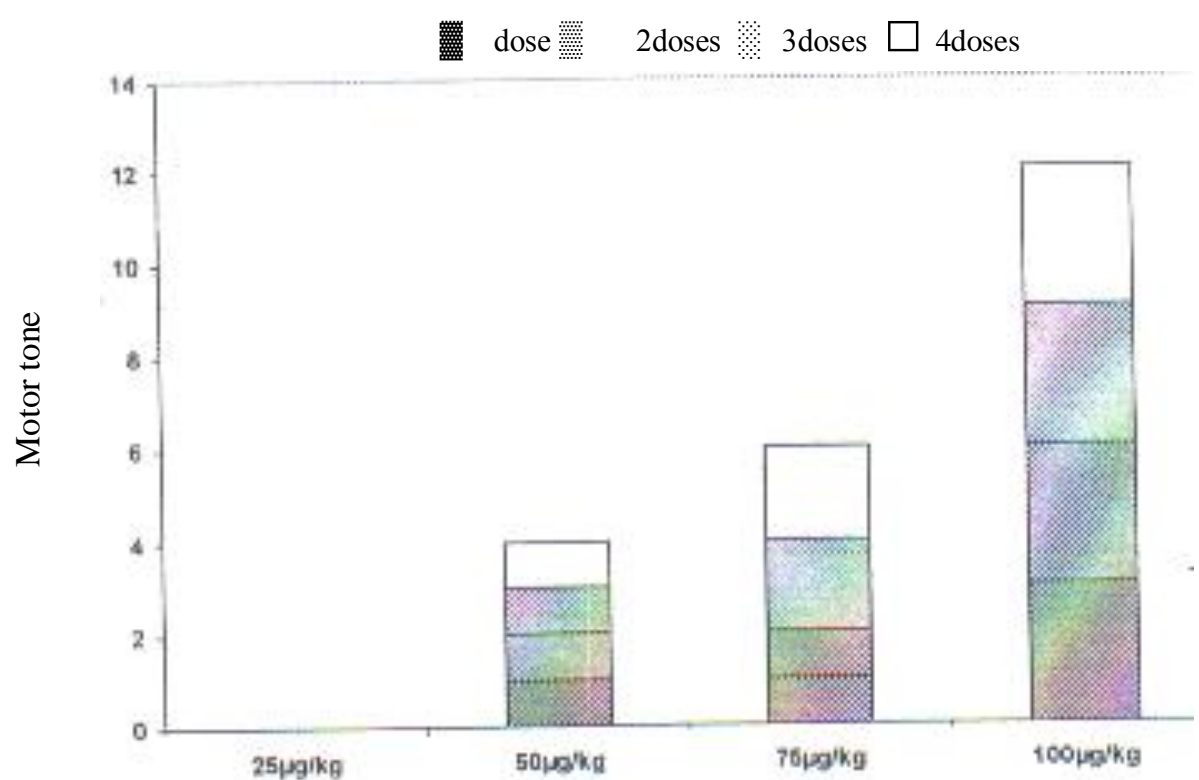

figure (13) : Effect of different doses of intrathecally injected neostigmine on motor tone .

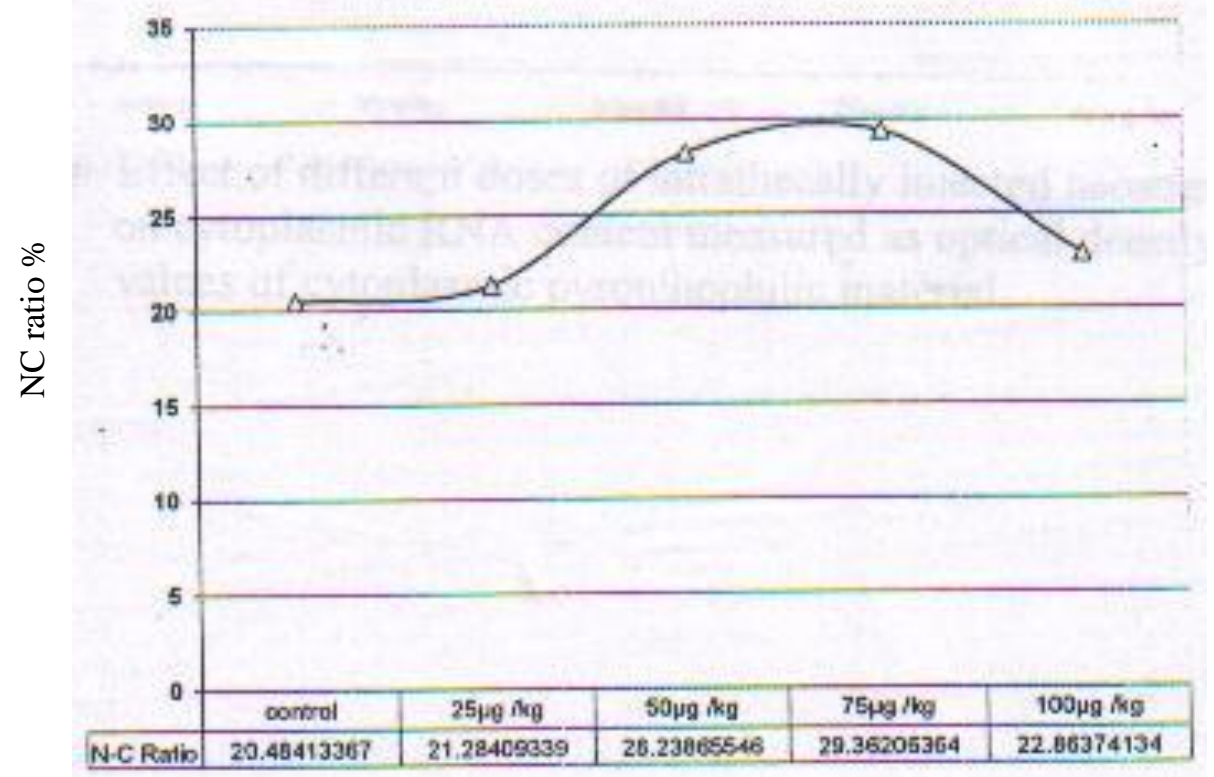

figure (14) : Effect of different doses of intrathecally injected neostigmine on nucleocytoplasmic ratio. 


\section{Some Pharmacological And Histological Studies}

Table(3): Mean optical density relative to pyronin stainability of Cytoplasmic RNA \pm The standard deviation (SD) in control and treated animals

\begin{tabular}{|lllrrl|}
\hline & Control & $25 \mu \mathrm{g} / \mathrm{Kg}$ & $50 \mu \mathrm{g} / \mathrm{Kg}$ & $75 \mu \mathrm{g} / \mathrm{Kg}$ & $100 \mu \mathrm{g} / \mathrm{Kg}$ \\
\hline Mean & 0.374586 & 0.39829 & 0.401058 & 0.381308 & 0.36748 \\
SD & 0.086412 & 0.046789 & 0.060104 & 0.046156 & 0.043459 \\
$\mathrm{P}$ & & $<0.001$ & $<0.001$ & $<0.001$ & $<0.001$ \\
\hline
\end{tabular}

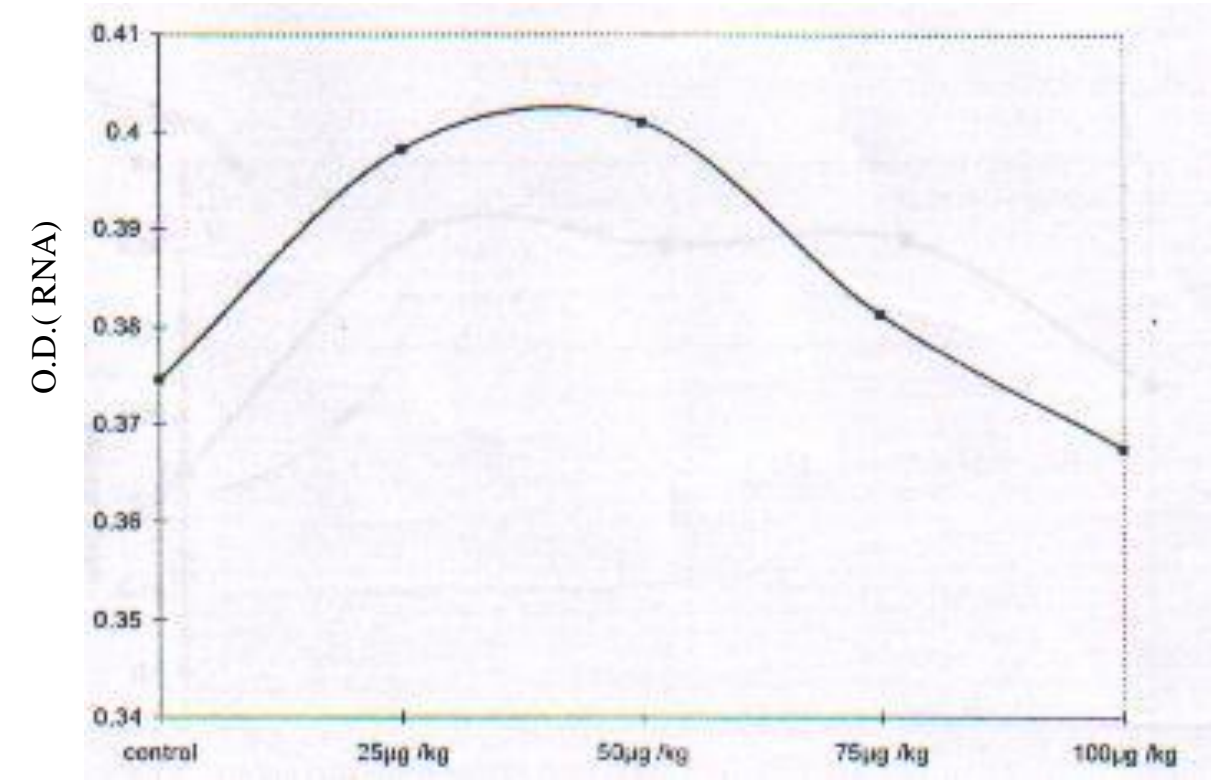

figure (15) : Effect of different doses of intrathecally injected neostigmine on cytoplasmic RNA content measured as optical density values of cytoplasmic pyroninophilic material.

Table (4) : Mean optical density relative to silver stainability of Golgi bodies \pm The standard deviation (SD) in control and treated animals

\begin{tabular}{|lrrrrr|}
\hline & Control & $25 \mu \mathrm{g} / \mathrm{Kg}$ & $50 \mu \mathrm{g} / \mathrm{Kg}$ & $75 \mu \mathrm{g} / \mathrm{Kg}$ & $100 \mu \mathrm{gg} / \mathrm{Kg}$ \\
\hline Mean & & & & & \\
O.D & 0.218752 & 0.361627 & 0.350981 & 0.354157 & 0.269317 \\
SD & 0.036161 & 0.121961 & 0.131755 & 0.105567 & 0.068102 \\
P & & $<0.001$ & $<0.001$ & $<0.001$ & $<0.001$ \\
\hline
\end{tabular}




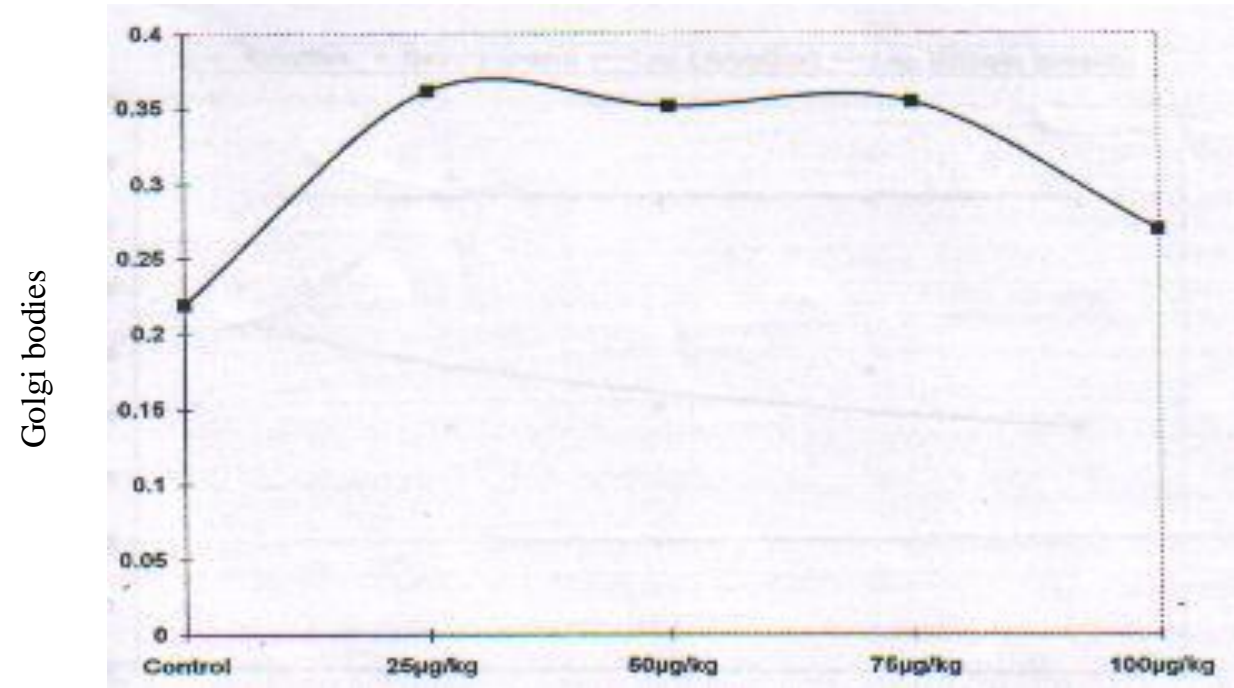

figure (16) : Effect of different doses of intrathecally injected neostigmine on Golgi bodies as measured from silver stained sections.

Table (5): Mean area occupied by nerve fibres relative to the total area of ventral horn \pm The standard deviation ( SD ) ; and the mean optical density relative to silver stainability of nerve fibers \pm The standard deviation (SD) in control and treated animals

\begin{tabular}{|cccccc|}
\hline & Control & $25 \mu \mathrm{g} / \mathrm{Kg}$ & $50 \mu \mathrm{g} / \mathrm{Kg}$ & $75 \mu \mathrm{g} / \mathrm{Kg}$ & $100 \mu \mathrm{g} / \mathrm{Kg}$ \\
\hline Area /box & $0.729 \pm 239$ & $0.785 \pm 233$ & $0.745 \pm 224$ & $0.752 \pm 228$ & $0.744 \pm 233$ \\
Density & $0.603 \pm 212$ & $0.385 \pm 0.086^{*}$ & $0.418 \pm 0.076^{*}$ & $0.479 \pm 0.04^{*}$ & $0.394 \pm 0.054^{*}$ \\
\hline
\end{tabular}

$\left(^{*}\right)$ The value is statistically significant compared to control $. P<0.001$

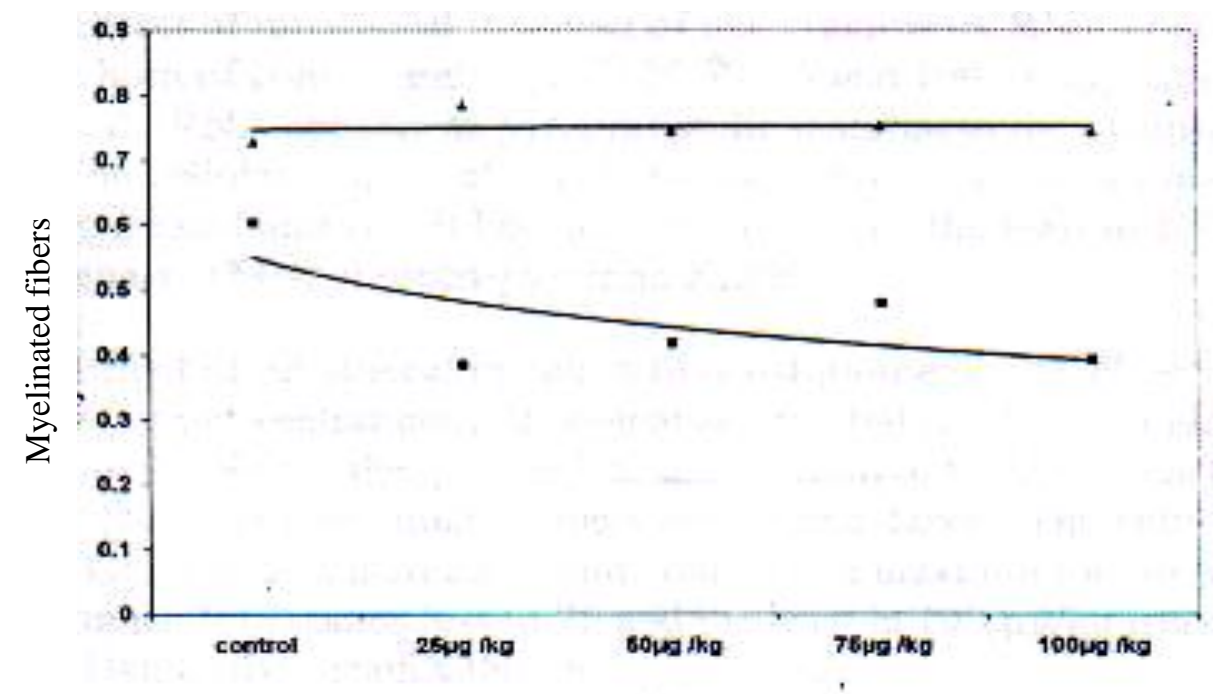

figure (17) : Effect of different doses of intrathecally injected neostigmine on the volume of myelinated fibers relative to the total tissue volume; and the density of silver stained myelin in control and treated animals. 


\section{Some Pharmacological And Histological Studies}

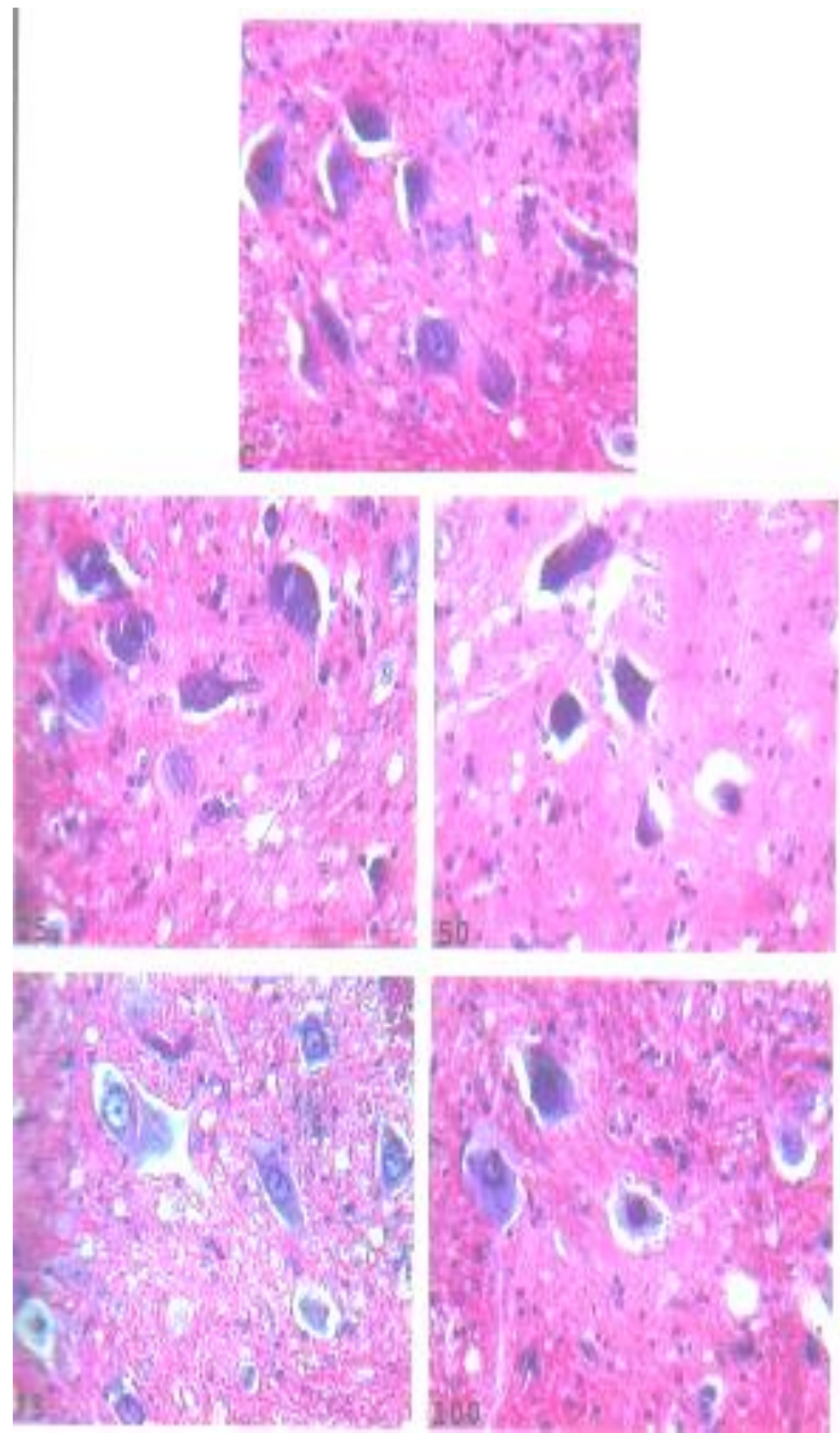

Plate (1) Effect of intrathecal injection of neostigmine on the general structurel of the ventral horn of control( $\mathrm{C}$ ) and treated $(25,50,75$ and $100 \mu \mathrm{g} / \mathrm{kg}$ ) animals .Notice the large Vesicular nuclei in the section from $75 \mu \mathrm{g} / \mathrm{kg}$ treated animals $(\mathrm{Hx}+\mathrm{EX} 250)$ 


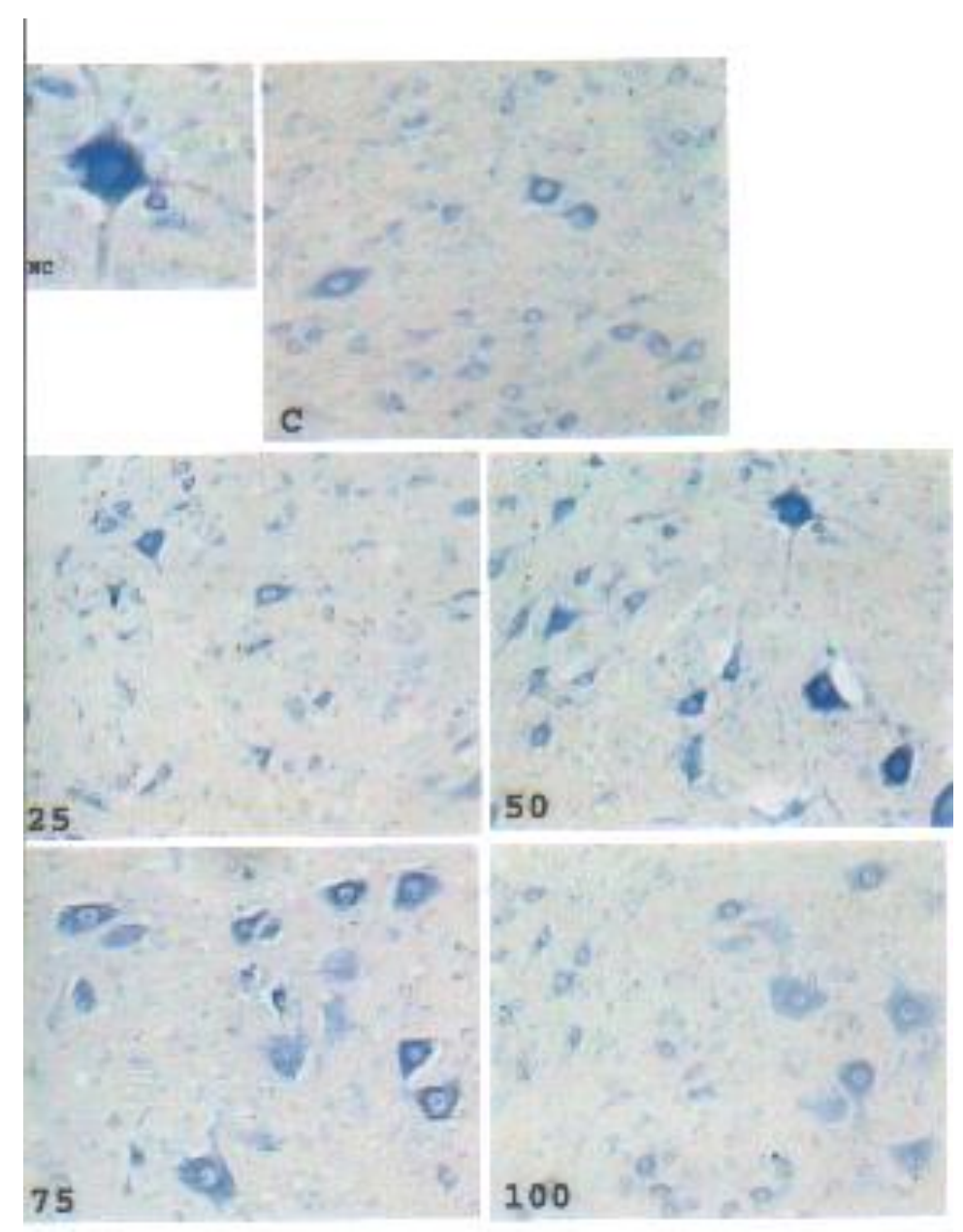

Plate ( 2) Effect of intrathecal injection of neostigmine on the distribution of Nissl granules of the ventral horn of control and treated $(25,50,75$ and $100 \mu \mathrm{g} / \mathrm{kg})$ animals . Notice the perinuclear distribution of Nissl granules in nerve cells (NC) . The cellular content of Nissl granules increases from control to a maximum in $50 \mu \mathrm{g} / \mathrm{kg}$ treated animals .It becomes less in 75 and the least in $100 \mu \mathrm{g} / \mathrm{kg}$ treated animals .( Toluidine blue X250) 


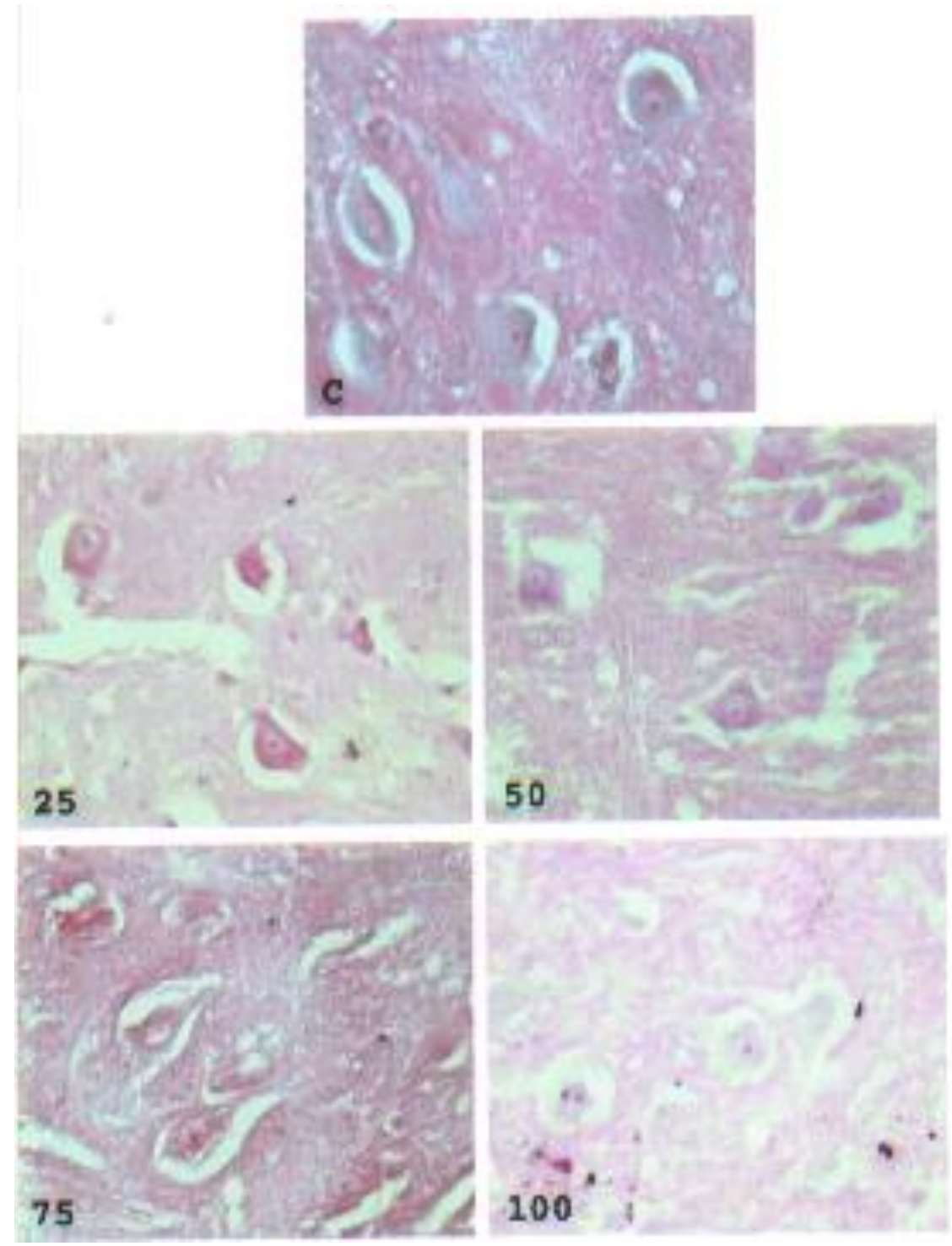

Plate ( 3) Effect of intrathecal injection of neostigmine on RNA content of the ventral horn of control and treated $(25,50,75 \mathrm{and} 100 \mu \mathrm{g} / \mathrm{kg})$ animals . Notice that the RNA appears as a pyroninophilic material in the cytoplasm and nuclei. The cellular content of RNA increases from control to a maximum in $50 \mu \mathrm{g} / \mathrm{kg}$ treated animals .It becomes less in 75 and the least in $100 \mu \mathrm{g} / \mathrm{kg}$ treated animals. (Methyl green-pyronineX250) . 


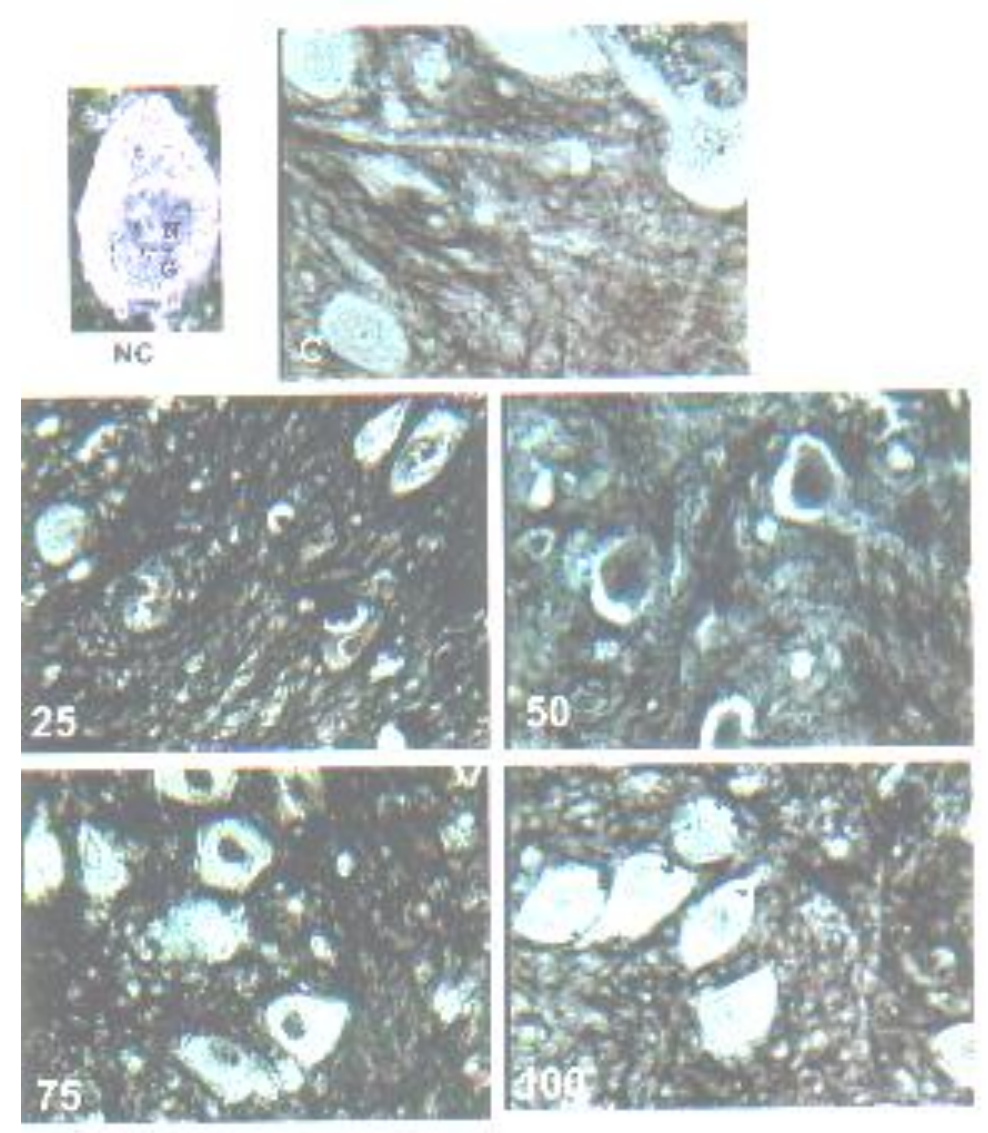

Plate ( 4) Effect of intrathecal injection of neostigmine on the silver stained components of control and treated $(25,50,75$ and100 $\mu \mathrm{g} / \mathrm{kg})$ animals . Notice the perinuclear distribution of Golgi bodies ( G ) in nerve cells ( NC) .The myelinated fibers are stained darkly. The cellular content of Golgi bodies increases from control to amaximum in $50 \mu \mathrm{g} / \mathrm{kg}$ treated animals .It becomes less in 75 and the least in $100 \mu \mathrm{g} / \mathrm{kg}$ treated animals (Nauta Silver stain X250) .

\section{Discussion}

The intrathecal injection of neostigmine into rats, resulted in dosedependent decreased arousal and motor coordination. This effect is due the inhibition of acetyl cholinesterase activity in brain and motor end plate (13). Gillberg et al. (12) observed similar motor effects in animals receiving intrathecal neostigmine or cholinergic agonists which are thought to be due to direct actions on motor neuron out flow rather than to ischemia or neurotoxicity.

In the present study, examination of motor tone revealed that the intrathecal injection of neostigmine resulted in an 


\section{Some Pharmacological And Histological Studies}

increase in motor tone which was evident by increased stiffness of the chest wall and the perception of tremors. Salivation was also noted and like motor tone this was dose dependent. These actions were considered as a reflect enhancement of spinal cholinergic activity secondary to inhibition of cholinesterase and were reported to be reversible by muscarinic antagonists $(17,25)$.

The general structure of the ventral column cells and fibers of control and treated animal spinal cord shows no clear cut changes. Yaksh et al.(25) and Hood et al.(13) demons trated that intrathecal neostigmine in large doses did not induce any histopathologic changes in the spinal cord. However, the results of the quantit -ative cytochemical and cytometric monitoring indicates signs of increased cellular activity at low doses and inhibitory action at high doses of neostigmine intrathecal injection.

the nucleo cytoplasmic ratio of the nerve cells increased as the dose increased up to $75 \mu \mathrm{g} . / \mathrm{kg}$ of intrathecal neostigmine injection, then decreased to a level higher than control in animals injected with $100 \mu \mathrm{g} / \mathrm{kg}$.

The increase plasmic ratio is a measure of nuclear activity in nucleic acid synthesis (3).. As the nerve cells are static cells that are not capable of division, and consequently DNA synth esis (23), the nuclear activity under the influence of intrathecal injection of neostigmine must be mainly in RNA transcription. The observed changes in cytoplasmic content of Nissl granules and cytoplasmic RNA in pyronin stained sections of the ventral horn cells supports this conclusion. The obtained values of optical density of pyronin ophilic material in the cytoplasm, which demonstrates ribosomal RNA engaged in protein synthesis, followed the same trend of nucleocytoplasmic ratio. Not only had that, but the accumulation of Golgi bodies, which is a manifestation of polypeptide processing (16), had, almost, the same trend. Collectively, the cytometric and cytochemical data indicate that intrathecal injection of neostigmine induces transcription, translation and processing of larger amounts of proteins. The protein which can be produced under these conditions is the cholinesterase enzyme. But, why should the neurons become active in cholinesterase synthesis after intrathecal injection of neostigmine?

The cholinesterase inhibitory activity of neostigmine has been reported to be due to its ability to act as a competitive inhibitor that binds to acetyl cholinesterase enzyme. By serving as alternative substrate with a similar binding orientation as acetylcholine, it gives rise to the carbamoylated enzyme. Sequestration of the enzyme in its carbamoylated form, thus, precludes the enzymecatalyzed hydrolysis of acetyl choline for extended periods of time. The return of the acetylcholinesterase activity depends on synthesis of new enzyme (24). Actylcholinestrase enzyme was reported to be synthesized in neuron perikaryon and was localized in the cisternae of rough endoplasmic reticulum (9).

Acetylcholine is an excitatory neurotransmitter for preganglionc sympathetic neurons. Intrathecal injec tion of cholinergic receptors agonists or cholinesterase inhibitors increases blood pressure through augmentation of sympathetic outflow (10).

In the present study intrathecal injection of neostigmine at doses $2-16$ $\mu \mathrm{g} / \mathrm{kg}$ induced a gradual increase in MBP of anesthetized cats which appeared 15 minutes and reached the peak 1 hour after injection. The onset latency for the effect of neostigmine could be explained by the lower lipophilicity of neostigmine resulting in longer time to its penetration of spinal cord tissue (20). Hood et al. (13) demonstrated that intrathecal injection of neostigmine produces hypertension which is mediated through local spinal actions by increasing synaptic conce ntration of acetyl choline. Also Pan et al.(20) proposed an effect through nitric oxide production which is thought to be an important mediator of acetyl choline.

In the present study, the hypertensive effect induced by intrathecal injection of neostigmine at doses $2-16 \mu \mathrm{g} / \mathrm{kg}$ were blocked by the muscarinic antagonist atropine and the alpha antagonist phentolamine indica ting that neostigmine injected 
intrathecally acts on muscarinic receptors. These results were consistent with Caraleau et al.(5), Williams et al.(27), Feldman (10) and Pan et al. (20) who demonstrated that the cholinergic actions of neostigmine are through muscarinic receptors mainly M2 receptors in the intermediolateral cell column while the analgesic effect of the drug was through M1 muscarinic receptors suggesting that cholinergically mediated analgesia and hemodynamic effect could be separated.

In this study, neostigmine (it) at doses 32 and $64 \mu \mathrm{g} / \mathrm{kg}$ produced a decrease in MBP of anesthetized cats. This effect could be due to central distribution of the drug and its action at cholinergic sites in the brain or due to its systemic absorption which are related to CSF neostigmine concentration (21).

In this study, spinal cat preparation showed that the increase in MBP with small doses of neostigmine (it) could be attributed to local spinal action, while the decrease in MBP with large doses could be due to central action.

Clonidine, an imidazoline compo -und, is a selective $\alpha 2$ adrenoceptor agonist with an $\alpha 2: \alpha 1$ activity ratio 200 : 1 . Centrally acting clonidine produces analgesia by activation of descending spinal cord and supraspinal inhibitory pathways. $\alpha 2$ receptors in the dorsal horn of the spinal cord modulate upward transmission of nociception signals by modifying local release of the nociceptive transmitters : substance $\mathrm{P}$ and calcitonin gene related peptide (CGRP). The cardiovascular effects of clonidine injected intrathecally (it) involve $\alpha 2$ adrenoceptors and imidaz oline receptors leading to a reduction in sympathetic tone and increase in parasympathetic tone resulting in a decrease in blood pressure and heart rate (1 ). Buccafusco and Margari (4) demonstrated that $\alpha 2$ adrenoceptor agonist and cholinergic combination is effective in producing analgesia while minimizing side effects.

In the present study, the injection of neostigmine (it) before clonidine (it) eliminates the clonidine induced hypot ension and bradycardia. This is consistent with the previous studies of Caraleau et al. (5)who pointed out a dense blinding of cholinergic ligands within the intermediolateral wall cell column and intrathecal injection or iontophoretic application of muscarinic agonist carbacol at this site increases blood pressure and heart rate. Also Williams et al. (27) noted a dense bind -ing of $\alpha 2$ adrenergic ligands in the intermediolateral cell column and intrathecal injection or iontphoretic application of clonidine at this site decreases sympathetic neural activity. These authors proposed that spinal injection of neostigmine counterbal ances clonidine effects in the interme diolateral cell column. Conclusion:The results observed in these two species (cats\&rats) demonstrated that intrath ecal injection of neostigmine produced variations in blood pressure and heart rate of cats and alterations in cellular activity of ventral horn column of rats conclusion.

These changes were dose dependent and were attributed to the effect of neostigmine on cholinesterase enzyme activity.These results provide additional support for the clinical trials of intrathecal injection of neostigmine for analgesia .

\section{References}

1- Aitkenhead A.R, Rowbotham D.J, Smith G. (2001) : Drugs acting on the cadiovascular and autonomic nervous system. In : Textbook of Anaesthesia. Ch 7; p 78-79.

2- Bartolini A, Ghelardini C, Fantetti L, Malcangio M, Malmberg Atello P, Giotti A (1992) : Role of muscarinic receptor subtype in central antinac iception. Br J Pharmacol. 105 : 77 - 82. 3- Bellamy W A (1974) : Biotechnology report :single cell proteins from cellulosic wastes .Biotechnol Bioeng 16(7):869-80

4-Buccafusco JJ and Margri V (1990) : The pressor response to spinal cholinergic stimulation in spontane ously hypertensive rats. Brain Res Bull. $25: 69-74$.

5-Caraleau FR, McKitrick DJ, Weernink EJ (1990) : Microinjection of substance $\mathrm{P}$ and $\mathrm{ACH}$ into rat intermediolateral nucleus elicits cardio vascular responses. Am J Physiol. 259 : R 357 - R 361. 


\section{Some Pharmacological And Histological Studies}

6- Clayden E S(1971):Practical section cutting and staining .Churchil livingstone ,Edinberg and london.

7- Detweiler DJ, Eisenach JC, Tong $C$, and Jacksom C (1993) : A cholinergic interaction in alpha 2 adrenoceptor-mediated antinociception in sheep. J Pharmacol. Exp Ther., 265 : $536-42$.

8- Drury R A B and Wallington E A (1980): Carleton's Histological Technique, $5^{\text {th }}$ ed. Oxford, New York, Toronto.

9-Dubovy P, Svizenka I, Vega J A (1990) Non-specific cholinesterase activity in mouse spinal ganglion. The usefulness of histochemichal study and image analysis for simple characte rization of neuron subclasses .Cell Mol Biolog p; 36(1) 23-40

10-Feldman DS, Terry AV, Buccafusco jj (1996) : Spinal muscarinic cholinergic and nitric oxide systems in cardiovascular regulation. Eur j.pharmacol 313 : 211-20.

11-Furchgott $R$ (1955) : The pharmacology of vascular smooth muscle. Pharmac Revision. 7 : 183.

12-Gillberg P G ,Hartving P, Gord T et al ( 1990 ) : Behavioral effects after intrathecal administration of cholinergic receptor agonists in the rats .Psychopharmacogy (Berlin) : 100(4) 464-9

13-Hood DD, Eisenach JC, Tong C, Tommasi E, Yaksh TL (1995) : Cardiorespiratory and spinal cord blood flow effects of intrathecal neostigmine methylsulphate, clonidine and their combination in sheep. Anesthesiology ,82:428-435.

14-Kehlet H (1998) : General versus regional analgesia. Principles and practice of anesthesiology. Longerecker DE, Tinker JH, Morgan GE editors $2^{\text {nd }}$ edition chap. 27. P. 1317 - 29. Mosby.

15-Kessler DA (1989) : The regulation of investigational drugs. N Engl J Med 320:277-288

16- Janqueira L C , Carneiro J ,Kelly R (1998) : Basic histology .

17-Naguib $M$ and Yaksh (1994): Antinociceptive effects of spinal cholinesterase inhibition and isobolo - graphic analysis of the interaction with the $\mu$ and $\alpha 2$ receptor system .Anesthesiology 80:1338-48

18-Nauta $W J$ and Gygax $P A$ (1951): Stain Technol. 26: 5-11. (Cited by Drury and Wallington, 1980)

19- Paget GE and Barnes YM (1964) : Toxicity tests in : evaluation of drug activities pharmacometrics. Eds Lawrance DR and Backarach AL, vol. 1, Academic Press, London and New York.

20- Pan HL, Dong HK, Eisenach JC (1998) : Effects of intrathecal neosti gmine, bupivacaine and their combin ation on vacaine and their activity in rats. Anesthesiology, $88: 481-486$.

21- Shafer S T ,Eisenach JC, Hood DP, Tong C (1998) : Cerebrospinal fluid pharmacokinetics pharmacodyna mics of intrathecal neostigmine methyl sulphate in humans .Anesthesiology 67: 889-95

22-Sjostrom S, Tamsen A, Person $P$, Hartvig P (1987) : Pharmacokinetics of intrathecal morphine and meperidine in humans. Anesthesiology $67: 889$ - 95

23-Stevens R A, Frey K, Lius S S et al (1997) : Sympathetic block during spinal anesthesia in volunteers using lidocaine, tetracaine and bupivacaine Regional Anesth 22(4) : 325-31

24-Taylor J R (2001) : Repeated intermittent administration of psychommotor stimulant drugs alters the acquisition of pavlovian approach behavior in rats ; differential effects of cocaine ,d-amphetamine and 3,4-methy lenedioxmethamphetamine ("Ecstasy "). 25-Yaksh TL,Grafe M R,Malkmus S AHT et al (1995): Studies on the safety of chronically administered intrathecal neostigmine methyl sulphate in rats and dogs .Anesthesiology 82:412-27

26-Weast,R.C.;Selby,S.M.;and

Hodgman,C.D. (1964): Handbook of Chemistry and Physics; 45 ${ }^{\text {th }}$ ed. The Chemical Rubber Co., Cleveland, Ohio, U.S.A.

27-Williams JS, Tong C, Eisenach JC (1993) : Neostigmine counteracts spinal clonidine-induced hypotension in sheep. Anesthesiology, 78 : $301-307$. 


\section{بعض الاراسات الفارماكولوجى و الهيستولوجي عن تأثير حقن النيوستجمين فى داخل الأم الجافية}

يؤدى حقن عقار النيوستجمين المثبط للكولين استريز اللى تسكين الألم و يزيد من الته

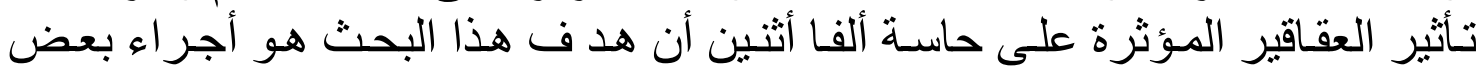

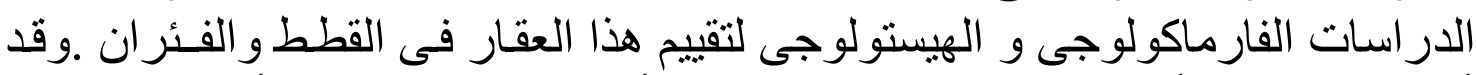

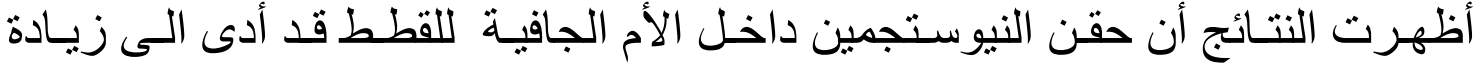

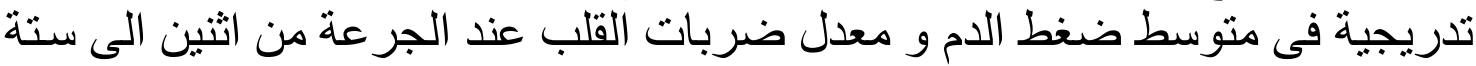

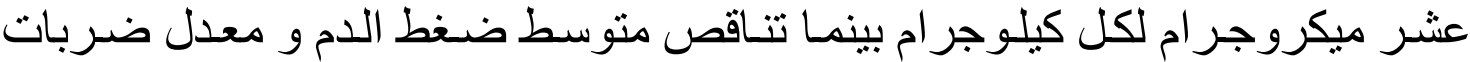

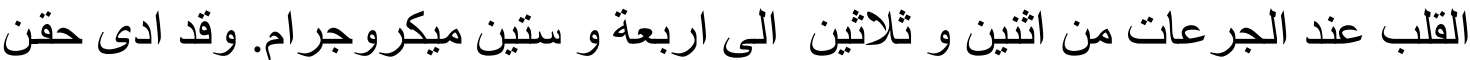

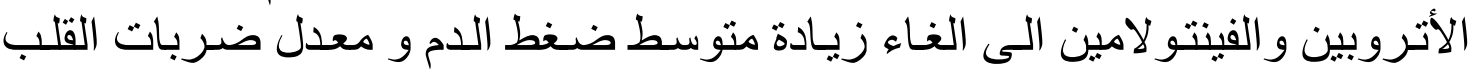

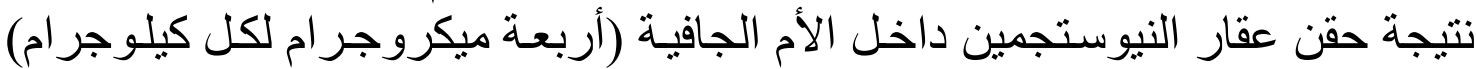

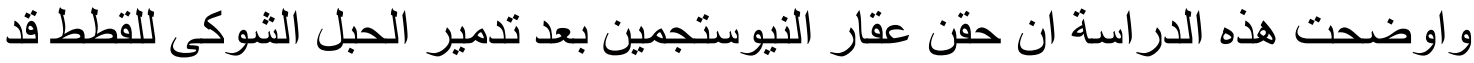

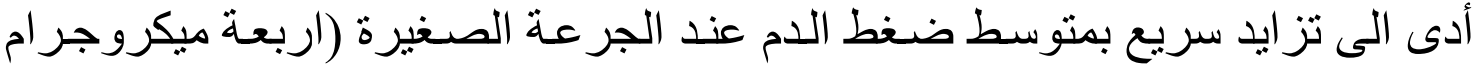

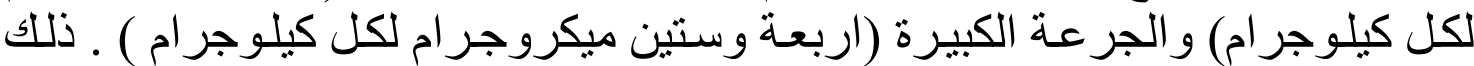

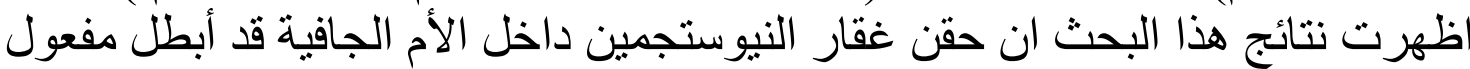

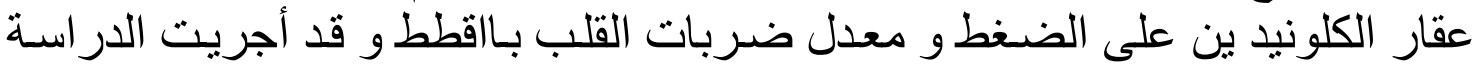

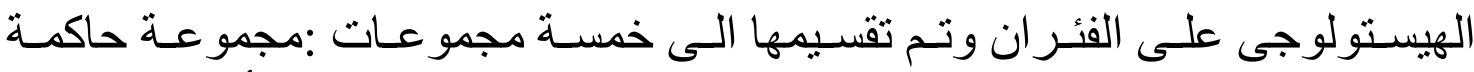

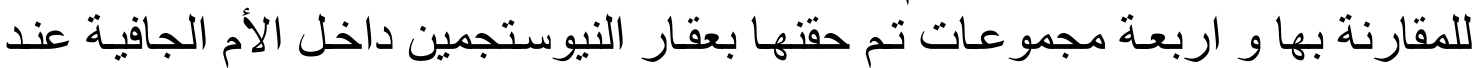

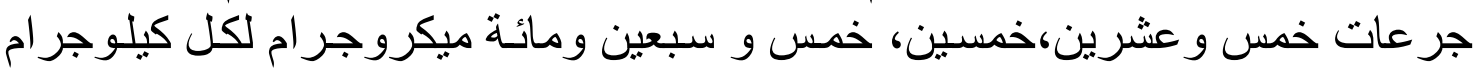

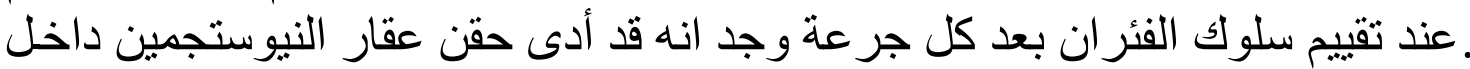

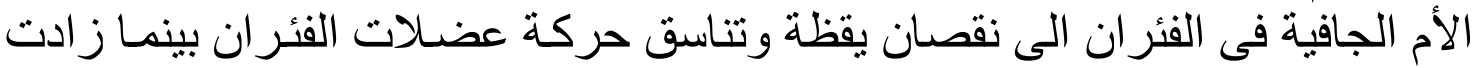

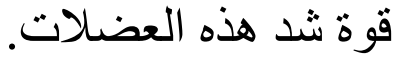

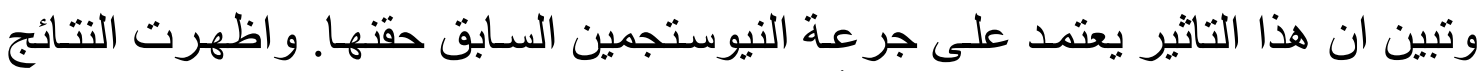

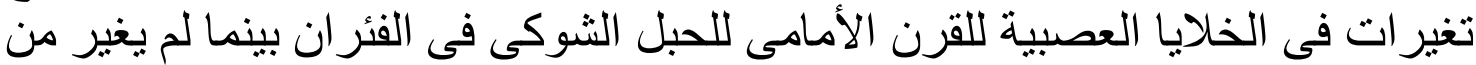

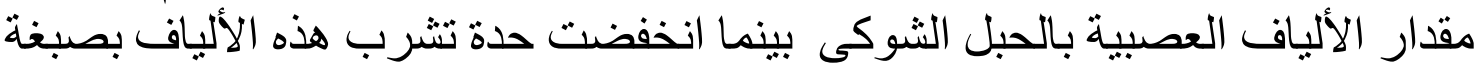

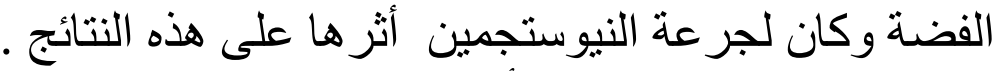

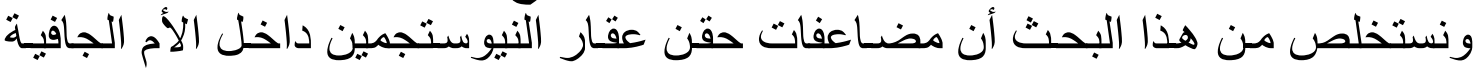
يعتمد على الجرعة السابق حقنهاو التى لابد أن أن يكون لها أهميتها فى التطبيق العملى التحلى 